\title{
THE ROLE OF IMMIGRATION IN SUSTAINING THE SOCIAL SECURITY SYSTEM: A POLITICAL ECONOMY APPROACH
}

\author{
EDITH SAND \\ ASSAF RAZIN \\ CESIFO WORKING PAPER NO. 1979 \\ CATEGORY 1: PUBLIC FINANCE \\ APRIL 2007 \\ Presented at CESifo AREa Conference on \\ Public SECTOR ECONOMICS, APRIL 2007 \\ An electronic version of the paper may be downloaded \\ - from the SSRN website: \\ www.SSRN.com \\ - from the RePEc website: \\ www.RePEc.org \\ - from the CESifo website: \\ www.CESifo-group.de
}




\title{
THE ROLE OF IMMIGRATION IN SUSTAINING THE SOCIAL SECURITY SYSTEM: A POLITICAL ECONOMY APPROACH
}

\begin{abstract}
In the political debate people express the idea that immigrants are good because they can help pay for the old. The paper explores this idea in a dynamic political-economy setup. We characterize sub-game perfect Markov equilibria where immigration policy and pay-as-yougo (PAYG) social security system are jointly determined through a majority voting process. The main feature of the model is that immigrants are desirable for the sustainability of the social security system, because the political system is able to manipulate the ratio of old to young and thereby the coalition which supports future high social security benefits. We demonstrate that the older is the native born population the more likely is that the immigration policy is liberalized; which in turn has a positive effect on the sustainability of the social security system.
\end{abstract}

JEL Code: H10.

Edith Sand

Tel Aviv University

Eitan Berglas School of Economics

Tel Aviv 69978

Israel

edit@post.tau.ac.il

\author{
Assaf Razin \\ Tel Aviv University \\ Eitan Berglas School of Economics \\ Tel Aviv 69978 \\ Israel \\ razin@post.tau.ac.il
}

April 23, 2007

We acknowledge Steve Coate and Jose-Victor Rios-Rull for insightful comments. 


\section{Introduction}

Economic analysis of the intergenerational and intragenerational aspects of the sustainability of social security has had a revival of sorts in recent time. Attention focuses on the direct impact of the population aging on pay-as-you-go social security system. In this context, migration is regarded by many as one of the necessary factors for the sustainability of the system, since it tend to reverse some consequences of the aging process. The purpose of this paper is to study how a political-economy equilibrium model, in which both migration and taxes interact, focusing on the intergenerational aspect of social security, works in the presence of aging.

All over the world, declining population growth rates and rising life expectancy trigger political-economy forces, which are likely to transform the social security system, as we know it. Due to these demographic changes, the EU population, in particular, is undergoing a long term trend of ageing, leading to a likely fall in the working population in the 25 states from 303 million to 297 million by 2020 . Two main aspects of the aging process are relevant to the political sustainability of social security systems. From an economic perspective, a rise in the dependency ratio (i.e., the proportion of retirees per worker) increases the number of people drawing from the system; while it decreases the number of contributors. From a political perspective, the older is the median voter, the more relevant is the pension spending in the political agenda. These two contradicting effects induced by the process of aging, which results in higher demand for, and lower supply of, social security influence also the political-economy debate about migration.

There is a large controversy in the economic literature regarding the overall fiscal influence of migration on host economies. Some argue that the net tax revenue generated by immigrants is not significant because immigrants consume much of the benefits they produce- especially in terms of health care and education. However, especially in light of the rapid demographic changes, migration is often viewed as a policy that may come to the rescue of pay-as-you-go social security systems, at least in the short run. This view reflects the fact that the flow of immigrants can alleviate the current demographic imbalance, by influencing the age structure of the host economy. Therefore, even if migration does not provide in itself a full-fledged long-term solution to falling birth rates and ageing population, migration policy is considered to be one of the available tools within a broader policy mix (such as a policy which admits immigrants based on their skills). 
Countries more often than not enact migration quotas, which are being decided upon in the political system. Thus, immigration must be viewed as an endogenous policy variable in the general equilibrium-political economy system, as much as the level of social security itself. The present paper assumes that both migration and social security policy variables as endogenous. It focuses on the pure intergenerational aspects of the migration cum social security sustainability. To isolate the intergenerational aspects we abstract from intragenerational income transfers considerations. The basic elements are of the model are standard in this literature. There is a pay-as-you-go social security system, which employs payroll taxes (at a flat rate) on a representative working young in order to finance a uniform benefit to the aged population. Immigrants enter the economy when young, and gain the right to vote only in the next period, when old. A crucial assumption, which derives the voter's strategy, is that immigrants have a higher population growth rate than the native-born. Thus, immigration is assumed to influence the age structure of the host economy, by effecting not only the current but also the future dependency ratio. Offspring of immigrants are assumed to be completely integrated into the country and have the same population growth as the native-born. The tax-migration policy is endogenously determined both by conventional effect on wages, savings, etc., and by strategic considerations, concerning the effect of the current tax-migration policy on the next period tax-migration policy. The model generates several equilibrium types. When the current migration policy is the only state variable, the Markov sub-game perfect equilibrium is characterized by a "demographic switching" strategy, where the young decisive voter admits only a limited number of immigrants, in order to change the decisive voter's identity from young to old in the next period. This strategy reflects the fact that immigrants are admitted in the host economy, because the political system is able to manipulate the ratio of old to young and thereby the coalition, which supports future high social security benefits. When next period capital per (native-born) worker is an additional state variable, there is yet another channel of influence of the current period policy variables on next period policy variables through savings. Thus, the young decisive voter may adopt a "demographic steady" strategy, where she admits the maximum amount of immigrant. In so doing the young decisive voter renders a majority for the young, every period. In this case, both "demographic switching" and "demographic steady" strategies are incorporated in the same equilibrium.

To understand the "demographic switching" strategy, we begin with a base line model, with no private saving traded assets, in which next period policy 
variables are influenced only by the current migration policy. The extended model with private savings and capital accumulation includes another equilibrium type (in addition to the one similar equilibrium as in the base line model). The new type features both a "demographic switching" strategy and a "demographic steady" strategy.

We characterize subgame-perfect Markov equilibrium paths for different patterns of population growth rates among the native-born and immigrants populations. We are thus able to demonstrate that the older are the native-born population the more likely is that the immigration policy is liberalized; which in turn has a positive effect on the sustainability of the social security system.

The paper is organized as follows. We survey related literature in Section 2. Section 3 provides analysis of the base line model, where there is no private savings, the economy does not accumulate capital, and factor prices are exogenous. Section 4 extends the base line model to include private saving, capital accumulation, and an endogenous determination of the wage and the interest rate. Section 5 considers the effect of aging in the extended model. Section 6 concludes.

\section{Literature Background}

An empirical investigation of the effect of the proportion of elderly people in the population on the size of social security benefit per retiree turn out not to be significant (Mulligan and Sala-i-Martin (1999) and Breyer and Craig (1997)) and also negative (Razin, Sadka and Swagel 2002a). Bergstrom and Hartman (2005) estimate the expected present value of benefits and costs to US voters for a small permanent increase in social security benefits. In addition, they explore the sensitivity of political support for social security and reach the conclusion that a once and for all decrease in benefits would be defeated by a majority of selfish voters. Cooley and Soares (1999), Bohn (2005), and Boldrin and Rustichini (2000) analyze the consequences of aging in a general equilibrium model of social security with production, which results in a rise in the size of social security systems. Models of altruism between generations reach the same conclusion (Tabellini (2000) and Hansson and Stuart (1989)). Analyzing the effect of interest groups on social security suggest ambiguous results. While some models emphasize the raise in the political power of the elderly (Verbon and Verhoeven (1992)), other models argue that aging will reduce social security, since larger groups experience higher deadweight costs and larger free rider effects, and will thus be less efficient in exerting political pressure (Becker and 
Mulligan (1998)). See also Galasso and Profeta (2002) for a survey.

Migration is often viewed as an economic force, which can mitigate the fiscal burden induced by the process of aging since an inflow of young working age immigrants may slow down population aging and help paying for social security. Because immigrants often have low education and high fertility rates, their net fiscal impact may be costly rather than beneficial. Storesletten (2000) and Lee and Miller (2000) calibrate a general equilibrium overlapping generations model to investigates whether a reform of immigration policies could resolve the fiscal problems associated with the aging. Storesletten finds that selective immigration policies, involving increased inflow of working-age high and medium-skilled immigrants, can remove the need for a future fiscal reform. Lee and Miller on the other hand reach the conclusion that since immigrants have lower education and higher fertility rates than that of the native-born, a higher amount of immigrant admitted into the economy will east temporarily the projected fiscal burden of retiring baby boomers in few decades although its overall fiscal consequences would be quite small. Feldstein (2006) argues that the common prescription of increased immigration would do little to reduce the future fiscal burden, and that the only alternative is to shift from a pure tax-financed system to a mixed system that supplements the tax financed benefits with benefits based on increased saving financial investment. Razin and Sadka (2000, 2004) address the issue of the fiscal burden associated with immigrants in a pay-as-you-go fiscal system. They show that the additional obligation of the fiscal system to pay pension benefits to the incoming migrants, when they retire, could be shifted forward indefinitely. If, hypothetically, the world would come to a stop at a certain point of time in the future, the young generation at that point would bear the deferred cost of the present migration. But in an ever-lasting economy, the migrants, by supplying work and helping the financing the pension benefit of period zero to native-born retirees, are a boon to the host country population: old, young, and future generations.

A pioneering paper which studied immigration policy in a political economy setup was the paper by Benhabib (1997). He examines the determination of immigration policies that impose capital and skill (human capital) requirements on heterogeneous immigrants through majority voting process. The model demonstrates that the native born population will be polarized between those who would like an immigration policy to maximize the domestic capital-labor ratio and those who would like to minimize it. Dolmas and Huffman (2004) and Ortega (2005) add another angle to the political debate and model the joint decisions over immigration quotas and redistributive tax policy. Both address the 
voting process in a dynamic set-up, where the native-born voters' preferences over immigration are influenced by the prospect that immigrants will be voting over future tax policy. The paper of Dolmas and Huffman refers to the decisions over immigration quotas and redistributive tax policy in subsequent three periods model with different degree of international capital mobility. The latter paper considers a infinite horizon general equilibrium model of immigration and redistribution policies, with a heterogeneously skilled population who chooses an immigration policy by majority vote while anticipating that immigration affects the skill premium and the skill composition of the electorate. Razin, Sadka and Swagell (2002b) show, in a stylized model of migration and human capital formation, that low-skill immigration may lead to a lower tax burden and less redistribution than would be the case with no immigration, even though migrants (naturally) join the pro-tax/transfer coalition. This is due to two conflicting effects of migration on taxation and redistribution. On the one hand, migrants who are net beneficiaries of the welfare state will join forces with the low income native-born voters in favor of higher taxes and transfers. On the other hand, redistribution becomes more costly to the native-born as the migrants share the redistribution benefits with them. These models clearly dial with intragenerational transfer, and not the intergenerational transfer as in a pure social security model. The present paper will extend this growing body of literature by analyzing the sub-game perfect Markov equilibria of a political-economy model, where the political decisions regarding migration and pay-as-you-go social security are jointly determined, focusing on the intergenerational aspect of social security.

\section{A Base Line Model}

The economy is populated by overlapping generations of identical individuals. Individuals live for two periods. When young, the representative individual works and makes a labor-leisure choice. Underdeveloped capital markets do not allow any private savings. Social security is therefore the only means of intertemporal transfers. When old, the individual retires, and receives social security benefits. The tax-transfer system is "pay as you go" where in every period the government levies a flat tax on the young's wage income, which fully finances the social security benefits paid to the old. Immigrants enter the economy when young, and gain the right to vote only in the next period, when old. They have the same preferences as those of the native-born, except from having a higher population growth rate. Immigrants are fully integrated into the social security system upon arrival into the country. Offspring of immigrants 
are like native-born in all respects (in particular, they have the same rate of population growth).

We assume that the utility of the representative young individual is logarithmic ${ }^{1}$, given by:

$$
\begin{gathered}
U^{y}\left(w_{t}, \tau_{t}, b_{t+1}\right)=\log \left[w_{t} l_{t}\left(1-\tau_{t}\right)-\frac{l_{t}^{\Psi+1}}{\Psi+1}\right]+\beta \log \left[b_{t+1}\right] \\
U^{o}\left(b_{t}\right)=b_{t}
\end{gathered}
$$

where $U^{y}$ and $U^{o}$ are the utility functions of young and old individuals, $\beta \in[0,1]$ is the discount factor, and $\Psi>0$ a labor- disutility parameter (also equals to the labor supply elasticity with respect to the wage rate). The transfer payments to the old at period $t, b_{t}$, are financed by collecting a flat income tax rate, $\tau_{t} \in[0,1]$, from the young individual's wage income at the same period, $w_{t} l_{t}$, where $l_{t}$ denotes hours worked.

Labor is a single input in the production of a homogenous final good. The production function is linear:

$$
Y_{t}=N_{t}
$$

where $Y_{t}$ and $N_{t}$ are period $t$ output and labor supply, respectively. Competitive equilibrium wage rate, which is equal to the marginal productivity of labor, is constant and normalized to unity. A worker can be either native-born or immigrant, perfectly substitutable, and with equal productivities. The immigration quotas is expressed as a certain percentage of the number of young individuals in the native-born population, $\gamma \in[0,1]^{2}$. Labor supply is:

$$
N_{t}=L_{t} l_{t}\left(1+\gamma_{t}\right)
$$

where $L_{t}$ is the number of young individuals in the native-born population (old people do not work).

Immigrants have the same preferences as the native-born population, but different population growth rates. We assume that the native-born population has a lower population growth rate, $n \in[-1,1]$, than that of the immigrant population, $m \in[-1,1]$, so that, $n<m$. We also assume that the immigrant's descendants are completely integrated into the economy and therefore have the

\footnotetext{
${ }^{1}$ Note that this type of utility function implies that there are no income effects on the demand for leisure (Greenwood, Hercowitz, and Huffman (1988)).

${ }^{2} \mathrm{~A}$ ceiling for $\gamma$ is set equal to one, which means that the number of immigrants cannot surpass the number of native born.
} 
same population growth rate as the native-born population does. The number of young native-born individuals at period $t$ :

$$
L_{t}=L_{t-1}(1+n)+\gamma_{t-1} L_{t-1}(1+m)
$$

In addition, immigrants are also assumed to contribute to, or benefit from, the social security system in the same way as the native-born. Because the social security system redistributes income from the young to the old, the balanced government budget constraint implies:

$$
b_{t+1} L_{t}\left(1+\gamma_{t}\right)=\tau_{t+1} w_{t+1} l_{t+1} L_{t+1}\left(1+\gamma_{t+1}\right)
$$

Re-arranging the expression yields:

$$
b_{t+1}=\frac{\tau_{t+1} w_{t+1} l_{t+1}\left[(1+n)+\gamma_{t}(1+m)\right]\left(1+\gamma_{t+1}\right)}{\left(1+\gamma_{t}\right)}
$$

Labor-leisure decisions of young individuals are derived, as usual, from utility maximization, taking the prices and policy choices as given:

$$
l_{t}^{\Psi}=w_{t}\left(1-\tau_{t}\right)
$$

Substituting for $b_{t}, b_{t+1}$ and $l_{t}$ in equations (7) and (8) into equation (1), the indirect utility functions of the young individual can be written as:

$$
\begin{aligned}
V^{y}\left(w_{t}, \tau_{t}, \tau_{t+1}, w_{t+1}\right)= & \log \left[\frac{\Psi}{\Psi+1} w_{t} l_{t}\left(1-\tau_{t}\right)\right]+ \\
& \beta \log \left[\frac{\tau_{t+1} w_{t+1} l_{t+1}\left[1+n+\gamma_{t}(1+m)\right]\left(1+\gamma_{t+1}\right)}{\left(1+\gamma_{t}\right)}\right]
\end{aligned}
$$

such that,

$$
\begin{gathered}
l_{t}^{\Psi}=w_{t}\left(1-\tau_{t}\right) \\
l_{t+1}^{\Psi}=w_{t+1}\left(1-\tau_{t+1}\right)
\end{gathered}
$$

Substituting for $b_{t}$ in equations (7) into equation (2), yields the indirect utility functions of the old individual:

$$
V^{o}\left(b_{t}\right)=\frac{\tau_{t} w_{t} l_{t}\left[(1+n)+\gamma_{t-1}(1+m)\right]\left(1+\gamma_{t}\right)}{\left(1+\gamma_{t-1}\right)}
$$

Note that the old individual prefers that the immigration quotas will be as large as possible, because more immigration would raise the total amount of tax 
collected, and thus the social security benefits she receives. The old preferable tax rate is the "Laffer point" tax rate, where the tax revenues, and therefore the social security benefits, are maximized. The tax rate at that point is equal to $\frac{\Psi}{\Psi+1}$.

The young individual prefers naturally that the current tax rate is as low as possible, namely zero. Concerning immigration quotas, the young preferences are ambiguous. On one hand, a larger quotas increases next period social security benefits per old individual. This is due to the fact that larger quotas increases the number of young in the next generation (some of these are offspring of the current immigrants) more than it increases the number of the old (who happen to be the current young) in the next period. This is due to the assumption that immigrants have a higher population growth rate than that of the native-born $(m>n)$. Thus, the number of next period old recipients of social security increases but the total sum of next period social security benefits increases even more. This means that next period social security benefits per old individual $\left(b_{t+1}\right)$ are higher the larger is the immigration quotas.

On the other hand, since immigrants gain the right to vote in the second period of their life, when old, the level of immigration quotas which affects the ratio of next period old to young voters also influences the identity of next period decisive voter. Lowering current immigration quota decreases the number of next period old voters less than it decreases the number of next period young voters (because we assumed $m>n$ ). Thus, voting for a low enough level of immigration quotas (below a certain a threshold level), would change the identity of the decisive voter from young to old in the next period. This will lead the current young voter which will be old in the next period, to favor the largest possible quota (due to its effect on next period transfer payments) which yet change next period decisive voter's identity from young to old in the next period.

\subsubsection{A Political-Economic Equilibrium}

We employ a subgame-perfect Markov equilibrium of perfect foresight, as our equilibrium concept (see Krusell and Rios-Rull (1996)):

Definition 1 A subgame-perfect Markov equilibrium is defined as a vector of policy decision rules, $\Psi=(T, G)$, where $T:[0,1] \longrightarrow[0,1]$, is the taxation policy rule, $T\left(\gamma_{t-1}\right)$, and $G:[0,1] \longrightarrow[0,1]$, is the immigration quotas policy rule, $G\left(\gamma_{t-1}\right)$, such that the following functional equation holds:

1. $\widehat{\Psi}\left(\gamma_{t-1}\right)=\arg \max _{\pi_{t}} V^{i}\left(\gamma_{t-1}, \pi_{t}, \pi_{t+1}\right)$ subject to $\pi_{t+1}=\Psi\left(\gamma_{t}\right)$, where 
$\pi_{t}=\left(\tau_{t}, \gamma_{t}\right)$ is defined as the vector of policy platform, and $V^{i}$ is the indirect utility of the current decisive voter.

2. The fixed-point condition requires that if next period policy outcome is derived by the vector of policy decision rules- $\Psi$, the maximization of the indirect utility of the current decisive voter will reproduce the same law of motion, $\widehat{\Psi}\left(\gamma_{t-1}\right)=\Psi\left(\gamma_{t-1}\right)$, as in 1 .

The policy variables, which are the tax rate, $\tau_{t}$, and the immigration quotas, $\gamma_{t}$, have to maximize the decisive voter's indirect utility function, while taking into account that next period political-economy policy rules depend on the current state variable, i.e. the current immigration quotas. Current and future political economy policy rules, as a function of state variables must be identical. Thus, the subgame-perfect Markov equilibrium notion states that the expected political-economy policy function, which depends on the current state variables, must be self-fulfilling.

The subgame-perfect Markov equilibrium is characterized by a "demographic switching" strategy. Assuming that immigrants enter the country while young and gain the right to vote only in the next period when they are old, voters take into account the effect of admitting a certain number of immigrants on the composition of voters and their voting preferences in the next period. Moreover, when the number of young exceed the number of old in the population, the young decisive voter admits a limited number of immigrants, in order to change the decisive voter's identity from young to old in the next period and maximize the next period benefits she receives.

The equilibrium path depends on the native-born and immigrant's population growth rates. If the population growth rates of the native-born and immigrants are both positive, there is a steady state with no taxation/social security benefits. If alternatively, the sum of the population growth rates is negative, there is also another steady state, but with a certain positive level of taxation/social security benefits (the "Laffer point" tax rate) and full openness to immigration. Otherwise, the sum of the population growth rates can be positive and the native-born population's population growth rate negative. In this case, there is a "demographic switching" equilibrium path where some quotas on immigration always prevails while there is an alternate period by period taxation/social security policy, depending on the identity of the decisive voter. In a given period there is a certain amount of taxation/social security benefits (the "Laffer point" tax rate) and no restrictions on immigration, while in the next there is no taxation/social security benefits and a more restrictive policy towards immigration. 
Since immigrants gain the right to vote only in the second period of their life in the host economy, the next period ratio of old to young voters who are allow to vote, denoted by $u_{t+1}$, is given by:

$$
u_{t+1}=\frac{\left(1+\gamma_{t}\right)}{(1+n)+\gamma_{t}(1+m)}
$$

Assuming that in case of a tie the old will be the decisive, the condition, $u_{t+1}<$ 1 , assures a majority of young individuals in the next period, while the condition, $u_{t+1} \geq 1$, assures a majority of old individuals. Therefore, the state variable of the economy, affects the next period ratio of young to old voters, $u_{t+1}$, which sets the profile of the next period decisive voter.

The Markov Perfect political equilibrium of the baseline model and its possible equilibrium paths, which depend on the population growth rates of the native-born and immigrant populations, can be formalized as follows:

Proposition 2 There exists an equilibrium with the following feature :

$$
\begin{aligned}
T\left(\gamma_{t-1}\right) & =\left\{\begin{array}{ccc}
\tau_{t}=0 & \text { if } & u_{t}\left(\gamma_{t-1}\right)<1 \\
\tau_{t}=\frac{\Psi}{\Psi+1} & \text { otherwise }
\end{array}\right. \\
G\left(\gamma_{t-1}\right) & =\left\{\begin{array}{ccc}
\gamma_{t}=-\frac{n}{m} & \text { if } \\
\gamma_{t}=1 & \text { otherwise }
\end{array} u_{t}\left(\gamma_{t-1}\right)<1\right.
\end{aligned}
$$

where $\gamma_{t}$ is restricted to be between zero and one. Under the assumption that the native-born population growth rate is lower than that of the immigrant's, there are three possible equilibrium paths, depending on the population growth rates of the native-born and immigrant population, as follows: 1 . if $n>0$, there is no taxation/social security benefits; 2. if $m+n<0$, migration quota is set at its maximum, and there is a positive level of taxation/social security benefits (the "Laffer point" tax rate). 3. if $n<0$ and $m+n>0$, there is a "demographic switching" equilibrium path, where some positive level of immigration always prevails while there is an alternate taxation/social security policy; in periods where the decisive voter is old, the economy is fully opened to immigration and there is a positive level of taxation (the "Laffer point" tax rate); whereas in periods where the current decisive voter is young, there is no taxation/social security benefits and a more restrictive policy towards immigration.

The proposition is proved in the appendix.

The interpretation of the proposition is as follows.

If the old-young ratio is smaller than one $\left(u_{t}<1\right)$, the decisive voter in the current period is a young voter. The young decisive favors naturally a zero tax 


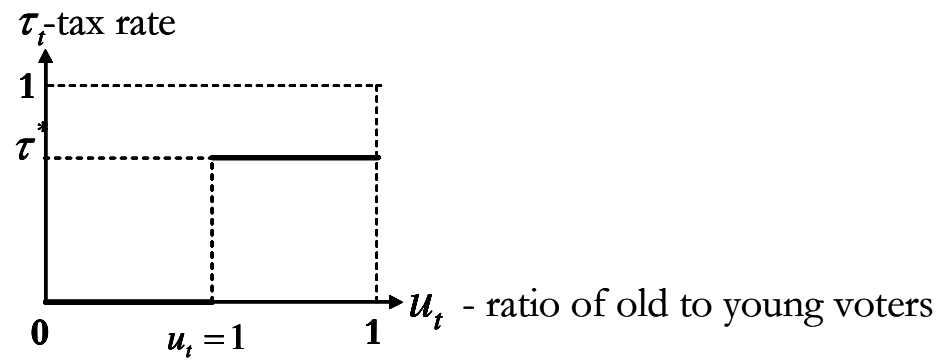

Figure 1:

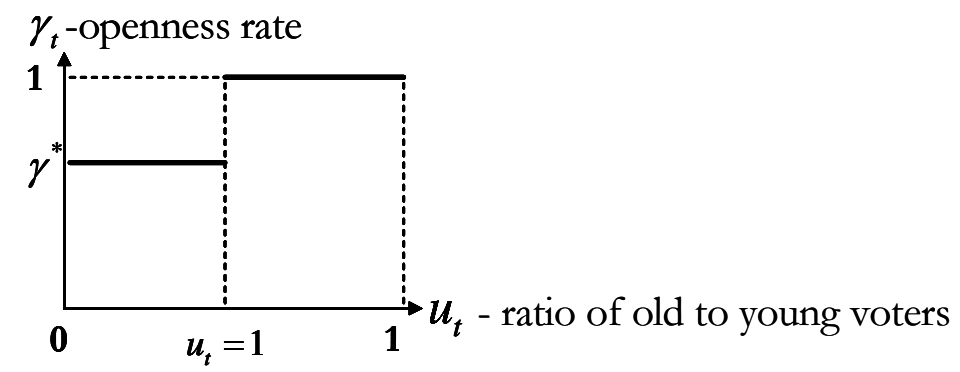

Figure 2: 
rate but has two conflicting considerations regarding the desired immigration quotas. One one hand, if there is full openness towards immigration: there will be more young working people in period $t+1$, and therefore, the tax revenue that which will be collected from a larger work force and needed to support retirement benefits, will increase. The young decisive voter in period $t$, who will be old in period $t+1$, would benefit from the more generous social security benefits. On the other hand, if the immigration policy is excessively large, the decisive voter in period $t+1$ will be a young voter. This voter will want to see the tax rate in period $t+1$ reduced to zero; hence no social security benefits whatsoever in period $t+1$. There is a threshold level of immigration quotas, $\gamma_{t}=-n / m$, which is exactly the level of the immigration policy that would equate the number of old and the number of young in period $t+1$. Thus, by choosing the immigration quotas at this level, the decisive voter in period $t$ would finely balance the two conflicting forces on period $t+1$ social security benefits, so as to maximize these benefits. Observe that this young voter's preferable immigration quotas is chosen strategically, aimed to influence the identity of the decisive voter in the next period from young voter to old.

If the old-young ratio is higher or equal to one $\left(u_{t} \geq 1\right)$, the decisive voter in the next period is an old voter. This voter will naturally vote for the most liberal immigration policy possible, because only the current social security benefits matter to this voter. The immigration quota is therefore equal to its maximum level (i.e., one). The tax revenue is set at the "Laffer point", where the tax rate is equal to $\frac{\Psi}{\Psi+1}$, because this way the current social security benefits are maximized.

There are three possible equilibrium paths depending on the population growth rates of the native-born and immigrant populations.

The first equilibrium path is the one where the population growth rate of the native-born and the immigrant population growth rate are both positive; that is, $n, m>0$. In this case, the level of social security benefits is zero. This is due to the fact that for every level of immigration, the number of next period young voters exceeds the number of next period old voters. Therefore, the decisive voter in the current and all the following periods is the young voter, and her preferences are for zero labor tax. The young voter is indifferent concerning the level of immigration because it has no influence on her current income, nor on the next period decisive voter's identity. The resulting equilibrium path is one in which there is a majority of young voters, and the social security system is dismantled, for ever. 
If the sum of the native-born and immigrant population growth rates is negative, $m+n<0$, the number of next period old voters always exceeds the number of next period young voters. Thus, along the equilibrium path a majority of old will always prevail, which validates a permanent existence for the social security system and a maximum flow of immigrants.

The third equilibrium path obtains if the native-born and immigrant populations growth rates are: $n<0$, and $m+n>0$. This equilibrium path is characterized by an alternate taxation/social security policy over two consecutive periods. Some positive level of immigration always prevails. This is due to a "demographic switching" strategy of the current and next period young voters. The reason is that when there is a majority of old, their preferable immigration quota is at the maximum and the tax rate is at the "Laffer point". Because $m+n>0$ and the old decisive voter allows as much as possible immigrants, the number of next period young voters exceed the number of next period old voters. Thus, in the next period the decisive voter must be the young. This voter opts for a zero tax rate, and does vote strategically on immigration levels. This means setting immigration at the threshold level, $\gamma_{t}=-n / m$. The identity of the next period decisive voter will change from young to old (a possibility of such demographic changes exists because the native-born population growth rate is negative while the immigrant population growth rate is positive). This creates a cycling effect of an alternate taxation/social security policy, with a certain level of immigration, depending on the identity of the decisive voter.

\section{The Extended Model: Private Saving, Capital Accumulation and Endogenous Factor Prices}

The base line model assumes zero private savings; hence no capital accumulation at all. In this section, we introduce private saving. This means that intertemporal transfers are both through private savings and through the social security system. The aggregate savings of the current young population generates next period aggregate capital. The latter is used as a factor of production, along with the labor input in the next period. The production function exhibits

constant return to scale. Another feature of the extended model is the wage rate, as well as the rate of interest, are endogenously determined along the equilibrium path. Social security benefits are financed, as before, by a payroll tax 
in a pay-as-you-go system ${ }^{3}$.

The utility of the representative young individual, as before, is logarithmic.

$$
\begin{aligned}
& U^{y}\left(w_{t}, \tau_{t}, s_{t}, r_{t+1}, b_{t+1}\right)=\log \left(w_{t} l_{t}\left(1-\tau_{t}\right)-s_{t}-\frac{l_{t}^{\Psi+1}}{\Psi+1}\right)+ \\
& \beta \log \left(b_{t+1}+\left(1+r_{t+1}\right) s_{t}\right) \\
& U^{o}\left(s_{t-1}, r_{t}, b_{t}\right)=b_{t}+\left(1+r_{t}\right) s_{t-1}
\end{aligned}
$$

where $r_{t}$ is the interest rate, and $s_{t}$ is the savings of the young at period $t$.

The production function is a Cobb-Douglas production function which is assumed to use both labor and capital as its factors of production:

$$
Y_{t}=N_{t}^{1-a} K_{t}^{\alpha}
$$

where $K_{t}$ is the aggregate amount of capital and $N_{t}$ is defined as in the previous section. The wage rate and interest rate are determined by the marginal productivity conditions (capital is assumed to depreciate completely at the end of the period):

$$
\begin{gathered}
w_{t}=(1-a)\left(1+\gamma_{t}\right)^{-a} l_{t}^{-a} k_{t}^{\alpha} \\
r_{t}=\alpha\left(1+\gamma_{t}\right)^{1-a} l_{t}^{1-a} k_{t}^{\alpha-1}-1
\end{gathered}
$$

where $k_{t}$ is capital per (native-born) worker. The balanced government budget constraint is derived as in the previous section:

$$
b_{t+1}=\frac{\tau_{t+1} w_{t+1} l_{t+1}\left[(1+n)+\gamma_{t}(1+m)\right]\left(1+\gamma_{t+1}\right)}{\left(1+\gamma_{t}\right)}
$$

The saving-consumption decision of young individuals are made by maximizing their utility while taking the prices and policy choices as given, and the labor-leisure decision is given as in the previous section:

$$
\begin{gathered}
s_{t}=\frac{1}{1+\beta}\left(\beta \frac{\Psi}{\Psi+1} w_{t} l_{t}\left(1-\tau_{t}\right)-\frac{b_{t+1}}{1+r_{t+1}}\right) \\
l_{t}^{\Psi}=w_{t}\left(1-\tau_{t}\right)
\end{gathered}
$$

The market clearing condition requires that the net domestic saving generates net domestic investment:

\footnotetext{
${ }^{3}$ To isolate the unique role of social security, the reader can compare the equilibrium types derived in appendix 7.4. The appendix assumes a similar model, but without a social security system.
} 


$$
s_{t}=k_{t+1}\left(\frac{1+n+\gamma_{t}(1+m)}{\left(1+\gamma_{t}\right)}\right)
$$

Solving for $b_{t+1}$ from equations (21) and (22), and substituting $b_{t+1}$ in equations (16) , the utility indirect function of the young can be written as follows:

$$
\begin{aligned}
& V^{y}\left(w_{t}, \tau_{t}, r_{t+1}, \tau_{t+1}\right)=\log \left(\frac{1}{1+\beta} \frac{\Psi}{\Psi+1} w_{t} l_{t}\left(1-\tau_{t}\right)\left(1+\beta f\left(\tau_{t+1}\right)\right)\right) \\
& +\beta \log \left(\frac{\beta}{1+\beta} \frac{\Psi}{\Psi+1} w_{t} l_{t}\left(1-\tau_{t}\right)\left(1+\beta f\left(\tau_{t+1}\right)\right)\left(1+r_{t+1}\right)\right)
\end{aligned}
$$

where $f\left(\tau_{t+1}\right)=\frac{\frac{1-\alpha}{\alpha} \frac{1}{1+\beta} \tau_{t+1}}{1+\frac{1-\alpha}{\alpha} \frac{1}{1+\beta} \tau_{t+1}}$, such that,

$$
\begin{gathered}
k_{t+1}=\frac{\beta}{1+\beta} \frac{\Psi}{\Psi+1} \frac{\left(1+\gamma_{t}\right) w_{t} l_{t}\left(1-\tau_{t}\right)\left(1-f\left(\tau_{t+1}\right)\right)}{1+n+\gamma_{t}(1+m)} \\
l_{t}^{\Psi}=w_{t}\left(1-\tau_{t}\right) \\
l_{t+1}^{\Psi}=w_{t+1}\left(1-\tau_{t+1}\right)
\end{gathered}
$$

and substituting $b_{t}$ from equation (21) and $k_{t}$ from equation (24), in equations (17), the indirect utility function of the old can be written as follows:

$$
\begin{aligned}
& V^{o}\left(\gamma_{t-1}, k_{t}, w_{t}, r_{t}, \tau_{t}\right)=\frac{\tau_{t} w_{t} l_{t}\left[(1+n)+\gamma_{t-1}(1+m)\right]\left(1+\gamma_{t}\right)}{\left(1+\gamma_{t-1}\right)}+ \\
& \left(1+r_{t}\right) k_{t}\left(\frac{1+n+\gamma_{t-1}(1+m)}{\left(1+\gamma_{t-1}\right)}\right)
\end{aligned}
$$

such that,

$$
l_{t}^{\Psi}=w_{t}\left(1-\tau_{t}\right)
$$

As in the previous analysis, the old individual favors a positive level of tax rate at a "Laffer Point" $\left(\tau^{*}=\frac{\Psi}{\Psi+1}\right)$, and the largest immigration quotas.

The preferences of the young, which will be discussed in the next section, differ from the baseline model as they are influenced by capital accumulation and endogenous factor prices effects.

\subsubsection{Political-Economic Equilibria}

The Markov sub-game Perfect equilibrium definition for the extended model is as follows:

Definition 3 A Markov perfect political equilibrium is defined as a vector of policy decision rules, $\Psi=(T, G)$, and private decision rule, $S$, where $T$ : $[0,1] \longrightarrow[0,1]$, is the tax policy rule, $\tau_{t}=T\left(\gamma_{t-1}, k_{t}\right)$, and $G:[0,1] \longrightarrow[0,1]$, 
is the immigration policy rule, $\gamma_{t}=G\left(\gamma_{t-1}, k_{t}\right)$, and $S:[0, \infty)->[0, \infty)$, is the saving decision rule, $k_{t+1}=S\left(\pi_{t}, k_{t}\right)$, such that the following functional equations hold:

1. $\widehat{\Psi}\left(\gamma_{t-1}, k_{t}\right)=\arg \max _{\pi_{t}} V^{i}\left(\gamma_{t-1}, \pi_{t}, \pi_{t+1}\right)$ subject to $\pi_{t+1}=\Psi\left(\gamma_{t}, S\left(\pi_{t}, k_{t}\right)\right)$.

2. $S\left(\pi_{t}, k_{t}\right)=\frac{\beta}{1+\beta} \frac{\Psi}{\Psi+1} \frac{\left(1+\gamma_{t}\right) w_{t} l_{t}\left(1-\tau_{t}\right)\left(1-f\left(\tau_{t+1}\right)\right)}{1+n+\gamma_{t}(1+m)}$, with $\tau_{t+1}=T\left(\gamma_{t}, S\left(\pi_{t}, k_{t}\right)\right)$.

3. The fixed-point condition requires that if next period policy outcome is derived by the vector of policy decision rules- $\Psi$, the maximization of the indirect utility of the current decisive voter subject to the law of motion of the capital stock, will reproduce the same law of motion, $\widehat{\Psi}\left(\gamma_{t-1}, k_{t}\right)=\Psi\left(\gamma_{t-1}, k_{t}\right)$, as in 1.

Policy variables have to maximize the decisive voter's indirect utility function, while taking into account the law of motion of capital and the fact that next period decision rules depend on the state variables, i.e. the current period immigration quotas and next period capital per (native-born) worker. Equilibrium paths depend on the native-born and immigrant population growth rates (as in the baseline model) and on the initial stock of capital per (native-born) worker.

There are two types of equilibria.

The first type, is characterized by a "demographic switching" strategy, similarly to the base-line model. When the decisive voter is young, she admits a limited number of immigrants in order to change the decisive voter's identity from young to old in the next period. The additional effect caused by the existence of savings and the endogeneity of factor price determination, is only quantitative.

The other equilibrium type is however different from the base-line model.

The additional state variable, the stock of capital per (native-born) worker, plays now a crucial role. Rational voters take into account that the current policy variables can affect next period policy variables not only through the composition of old to young voters, but also through the effect on next period capital per (native-born) worker; the additional state variable. There is another possible strategy of the young; a "demographic steady" strategy, where the equilibrium tax rate is a decreasing function of the capital per (native-born) worker, and migration quota is set at its maximum level. This level of immigration quotas renders a majority for the young in every period. The new equilibrium of the extended model, combines strategies concerning both the old-young composition in the population, and the level of capital: there is a range of values of the capital per (native-born) worker, for which the "demographic steady" strategy dominates; while for values outside this range, the "demographic switching" 
strategy dominates.

In the first type of Markov sub game Perfect equilibrium (referred to by "demographic switching strategy" equilibrium) policy rules do not depend on the capital per (native-born) worker state variable.

Proposition 4 There exists an equilibrium with the following feature:

$$
\begin{aligned}
& T\left(\gamma_{t-1}\right)=\left\{\begin{array}{ccc}
\tau_{t}=0 & \text { if } & u_{t}\left(\gamma_{t-1}\right)<1 \\
\tau_{t}=\frac{\Psi}{1+\Psi} & \text { otherwise }
\end{array}\right. \\
& G\left(\gamma_{t-1}\right)=\left\{\begin{array}{cc}
\gamma_{t}=\operatorname{Min}\left[\gamma^{*},-\frac{n}{m}\right] & \text { if } \\
\gamma_{t}=1 & \text { otherwise }
\end{array} u_{t}\left(\gamma_{t-1}\right)<1\right. \\
& S\left(\pi_{t}, k_{t}\right)=\left\{\begin{array}{lr}
S\left(\pi_{t}, k_{t}, \tau_{t+1}=\frac{\Psi}{1+\Psi}\right) \text { if } u_{t}\left(\gamma_{t-1}\right)<1 & \text { if } \begin{array}{l}
n<0 \\
S\left(\pi_{t}, k_{t}, \tau_{t+1}=0\right) \text { otherwise }
\end{array} \\
S\left(\pi_{t}, k_{t}, \tau_{t+1}=\frac{\Psi}{1+\Psi}\right) & \text { if } m+n<0 \\
S\left(\pi_{t}, k_{t}, \tau_{t+1}=0\right) & \text { otherwise } n>0
\end{array}\right.
\end{aligned}
$$

where $\gamma_{t}$ is restricted to be between zero and one, and $\gamma^{*}$ is given explicitly in the appendix. The equilibrium paths depend on the population growth rates and on the initial amount of capital per (native-born) worker the economy is endowed with. There are three main types of equilibrium paths which are similar to the previous section:1. if $n>0$, there is no taxation/social security benefits, and there are some restrictions on immigration. 2. if $m+n<0$, migration quota is set at its maximum, and there is a positive level of taxation/social security benefits (the "Laffer point" tax rate). 3. if $n<0$ and $m+n>0$, there is a "demographic switching" equilibrium path, where some positive level of immigration always prevails while there is an alternate taxation/social security policy; in periods where the decisive voter is old, the economy is fully opened to immigration and there is a positive level of taxation (the "Laffer point" tax rate); whereas in periods where the current decisive voter is young, there is no taxation/social security benefits and a more restrictive policy towards immigration.

The proposition is proved in the appendix.

The intuition is the same as in section 2. Because the decision rules in type one equilibrium do not depend on the capital per (native-born) worker, the Markov sub game Perfect equilibrium of the base line model is essentially a reduced form of this equilibrium. The equilibrium paths depend on the nativeborn and immigrant's population growth rates as in the baseline model, but naturally are also quantitatively influenced by the amount of initial stock of 
capital per (native-born) worker. The larger the initial stock of capital, the higher is the amount of capital accumulated every period.

The second type of Markov Perfect equilibrium of the extended model (referred to as "combined strategy" equilibrium) is specified as follows:

Proposition 5 Under several conditions on the parameters of the model, which are specified in the appendix, there exists another equilibrium type, with the following features:

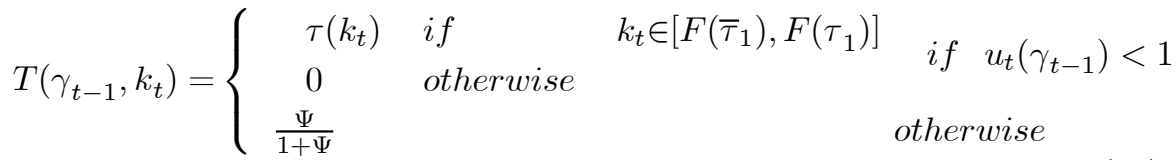

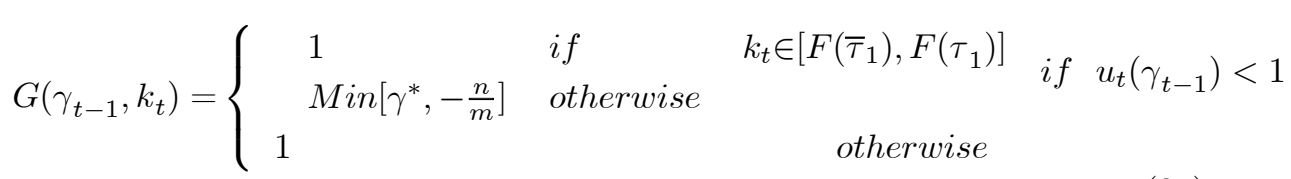

$$
\begin{aligned}
& S\left(\pi_{t}, k_{t}\right)=
\end{aligned}
$$

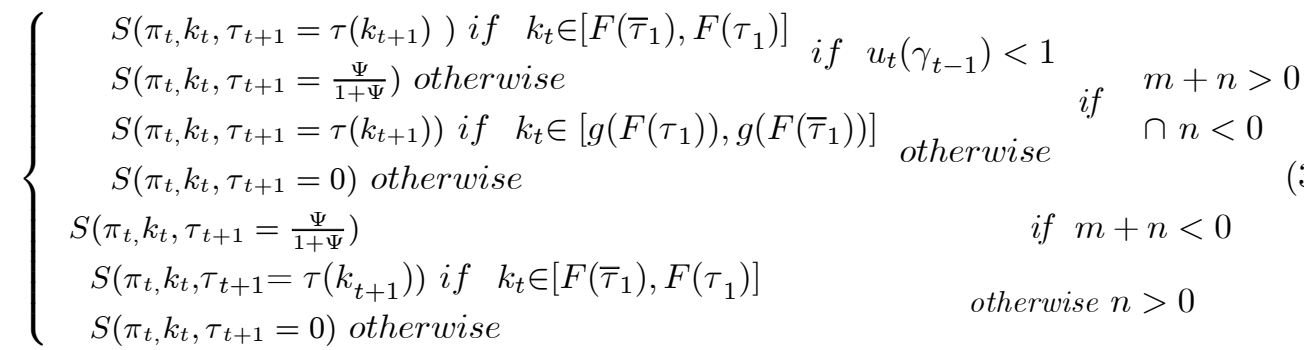

where $x=1+\frac{(1+\Psi) \alpha \beta}{\Psi+\alpha}$ and $g(F), F(\tau)$ and $\bar{\tau}_{1}$ are given in the appendix. The equilibrium tax rate, $\tau\left(k_{t}\right)$, is a decreasing function in $k_{t}$. The equilibrium paths, depends on the native-born and immigrant population growth rates and on the initial capital the economy is endowed with: 1 . if $n>0$ and $k_{o} \in\left[F\left(\bar{\tau}_{1}\right), F\left(\tau_{1}\right)\right]$, there is a "demographic steady" equilibrium path, characterized by a positive tax rate which depends on the capital per (native-born) worker state variable and migration quota is set at its maximum. If $k_{o} \notin\left[F\left(\bar{\tau}_{1}\right), F\left(\tau_{1}\right)\right]$, there are at least few periods in which there is no taxation/social security benefits and there are some restrictions on immigration. 2. if $m+n<0$, migration quota is set at its maximum, and there is a positive level of taxation/social security benefits (the "Laffer point" tax rate). 3. if $n<0$ and $m+n>0$, there is a range of 
$k_{o}{ }^{4}$, for which there is a "demographic steady" equilibrium path, characterized by a positive tax rate which depends on the capital per (native-born) worker state variable and no restrictions on immigration. If $k_{o}$ is not in this range, there are at least few periods in which there is a "demographic switching" equilibrium path, characterized by an alternate taxation/social security policy where some positive level of immigration always prevails; in periods where the decisive voter is old, the economy is fully opened to immigration and there is a positive level of taxation (the "Laffer point" tax rate); whereas in periods where the current decisive voter is young, there is no taxation/social security benefits and a more restrictive policy towards immigration.

The proposition is proved in the appendix.

The additional equilibrium path in the extended model are characterized by different optimal strategy of the young, depending on the values of the capital per (native-born) worker: for a range of values of the capital per (native-born) worker state variable the decision rules of the young decisive voter do not change the next period decisive voter's identity, while for other values of the capital per native-born work force the "demographic switching" strategy is still optimal. When the "demographic steady" strategy is optimal, the tax rate depends negatively on the amount of capital per (native-born) worker and there are no restrictions on immigration.

The equilibrium tax rate of the "demographic steady" strategy, is a decreasing function of capital per (native-born) worker. This is due to the fact that there are two conflicting forces of the effect of the next period tax rate on next period capital per native-born workers. On one hand, a higher tax rate in the next period raises future social security benefits. Larger benefits, tend to reduce current savings. This would cause a reduction in next period capital per nativeborn work force ("Effect One"). On the other hand, a higher next period tax rate tend to decrease the amount of hours worked next period which lowers the next period interest rate and social security benefits. The consequent fall in the current young future income induces more savings. This tends to increase next period capital per (native-born) worker ("Effect Two"). Since "Effect One" is stronger than "Effect Two", the tax rate is decreasing in the amount of capital per (native-born) worker ${ }^{5}$. There are no restrictions on immigration since larger immigration quotas has an additional positive effect on the indirect utility

\footnotetext{
${ }^{4}$ The range is defined as follows: if there is a majority of old (i.e. $u_{o} \geq 1$ ) the range of the initial capital per (native born) worker is: $\left[g\left(F\left(\tau_{1}\right)\right), g\left(F\left(\bar{\tau}_{1}\right)\right)\right]$; otherwise, the range is: $\left[F\left(\bar{\tau}_{1}\right), F\left(\tau_{1}\right)\right]$.

${ }^{5}$ This equilibrium property of the tax function, is already noted by Forni (2005).
} 
of the young. Due to the fact that "Effect One" is stronger than "Effect Two", larger immigration quotas which increase next period tax rate (since it decreases next period capital per (native-born) worker ${ }^{6}$ ), raise next period future social security benefits. This additional positive effect of immigration quotas on the indirect utility of the young raises the preferable immigration quotas leading to no restriction on immigration.

The reason for the additional strategy (i.e. the "demographic steady" strategy) in the "combined strategy" equilibrium, results from the additional state variable- the capital per (native-born) worker, which influences next period policy variables. When the capital per (native-born) worker is an additional state variable, the decisive young voter does not have to engage in a strategy of influencing next period policy variables only by changing next period decisive voter's identity through immigration quotas (meaning by admitting a limited amount of immigrants). Because both current policy variables, the tax and the migration quota, influence the amount of capital per (native-born) worker; which, in turn, influences next period policy variables. Moreover, the young can use the "demographic steady" strategy (instead of the "demographic switching" strategy), which is optimal for low enough capital per (native-born) worker ${ }^{7}$. This is due to the fact that low capital per (native-born) worker adds a positive effect on the indirect utility of the young in the case of the "demographic steady" strategy: it decreases the current wage income of the young which by reducing the amount of next period capital per (native-born) worker, leads to an increase in the next period tax rate and benefits (since "Effect One" is stronger than "Effect Two"). This raises the young future income, meaning that for low enough capital per (native-born) worker the "demographic steady" strategy is the dominant strategy.

The equilibrium paths depend on the population growth rates and the amount of capital per (native-born) worker:

1. The population growth rates of the native-born and immigrant populations are positive, $n, m>0$. In this case, the number of next period young

\footnotetext{
${ }^{6} \mathrm{~A}$ larger immigration quotas increases the number of young who save leading to higher aggregate capital accumulation in the next period. But since we assumed that $m>n$, immigration quotas increases even more the number of next period young. Thus the amount of next period capital per native-born work force decreases.

${ }^{7}$ The reason that the "demographic steady" strategy is optimal for a closed range of capital per (native born) worker instead of every capital per (native born) worker lower than some threshold, is that the tax rate is assumed to be positive and smaller than one. Since the tax rate is a function of the capital per (native born) worker, it means that the capital per (native born) worker should also be in a specific range (see the second part of the proof in appendix III).
} 
voters exceeds the number of next period old voters, which means that the decisive voter is always young. Therefore, if the initial capital per (native-born) worker is in the range $\left[F\left(\bar{\tau}_{1}\right), F\left(\tau_{1}\right)\right]$, there is a "demographic steady" equilibrium path, where the optimal strategy of the young is always to vote for no restrictions on immigration and a positive tax rate which depends on the capital per (native-born) worker. If the initial capital is not in the range $\left[F\left(\bar{\tau}_{1}\right), F\left(\tau_{1}\right)\right]$, zero tax rate and a positive immigration quotas are chosen by the young. Capital evolves in a way that it is possible to have a period where the amount of capital per (native-born) worker enters the range $\left[F\left(\bar{\tau}_{1}\right), F\left(\tau_{1}\right)\right]$; if it does, from then on the current young again vote for no restrictions on immigration and a tax rate which depends on the capital per (native-born) worker.

2. If the sum of the population growth rates is negative, $n<0$, then the number of old voters always exceeds the number of young voters. This means that the decisive voter is always old. In that case the old sets the tax rate at the "Laffer point", and no restrictions on immigration.

3 . If the sum of the population growth rates is positive, but the nativeborn population growth rate is negative, $n<0$ and $m+n>0$, there are two possible equilibrium path types. If the initial capital per (native-born) worker is in a certain range (defined in the proposition), there is a "demographic steady" equilibrium path where the optimal strategy of the young is to set a tax rate that depends on the capital per (native-born) worker, and to set no restrictions on immigration. If the initial capital per (native-born) worker is outside this range, there is a "demographic switching" equilibrium path where some level of immigration always prevails and there is an alternate taxation policy. Capital evolves over time in a way that there could be a period where the capital per (native-born) worker enters the relevant range; Once in this range, the optimal strategy of the young is to set a tax rate that depends on the capital per (nativeborn) worker, and to set no restrictions on immigration.

\section{The Effect of Aging}

We are now in position to conduct a comparative dynamics across demographic regimes. We analyze the effect of aging of the native born population on the size of the social security system and on immigration restrictions. Aging of the population is specified by a reduction in the population growth rate of the population (life expectancy is assumed to be exogenously fixed).

Proposition 6 1. Aging of the native born population can move the system to 
an equilibrium path with a certain level of taxation/social security benefits (the "Laffer point" tax rate) and no restrictions on immigration.

2. The aging of the native-born population enlarges immigration quotas set by the young in the "demographic switching" equilibrium path, while decreasing the tax rate in the "demographic steady" equilibrium path.

3. In the "combined strategy" equilibrium, aging can move the system from a "demographic switching" equilibrium path to "demographic steady" equilibrium path; or vise versa.

The intuition of the result is as follows. Sharp aging trend of the native-born population, can move the system to an equilibrium path where the sum of the population growth rates are negative, $n+m<0$. In this case, the old are in the majority every period. The old liberalize immigration policy as much as possible and sustain the social security system by setting the tax rate at the "Laffer point".

Aging of the native-born population increases the political-economy determined immigration quota when the young is in the majority. This quota, $\gamma_{t}=\operatorname{Min}\left[\gamma^{*},-\frac{n}{m}\right]$, is what is chosen by the current young in the "demographic switching" equilibrium path. The effect of aging of the native-born population on immigration policy works itself out through the ratio of old to young voters in the next period, $u_{t+1}=\frac{\left(1+\gamma_{t}\right)}{(1+n)+\gamma_{t}(1+m)}$. This dependency ratio effects the political-economy quota as follows: in the case where $\gamma_{t}=-\frac{n}{m}$, the dependency ratio effects the quota through the identity of next period decisive voter; whereas in the case where $\gamma_{t}=\gamma^{*}$, the dependency ratio effect goes through next period capital per (native born) worker (this results from the fact the effect of the quotas on the ratio, $u_{t+1}$ : larger quota increases the amount of total savings but since there are also more young in the next period, it has the overall effect of decreasing the capital per (native born) worker)). Since a larger quota decreases the ratio of next period old to young voters (it increases the number of next period immigrant descendants more than the number of next period old immigrant), it will decrease the ratio of next period old to young voters less the lower is the native born population growth rate. Thus, aging has the overall effect of raising the optimal immigration quota of the young voter in the "demographic switching" equilibrium path.

Aging of the native-born population also decreases the tax rate set by the young in the "demographic steady" equilibrium path, $\tau\left(k_{t}\right)$. This is due to the fact that aging increases total savings which raises the amount of capital per (native-born) worker. Since the tax rate is a decreasing function of the capital per (native-born) worker state variable, the aging of the native-born population 
decreases the optimal tax rate in the "demographic steady" equilibrium path.

Aging affects the capital per (native-born) worker, and thus can move the system from the "demographic switching" equilibrium path to the "demographic steady" equilibrium path or vise versa, since the equilibrium paths are defined over a closed range of the capital per (native-born) worker state variable.

\section{Conclusion}

In the political debate people express the idea that immigrants are good because they can help pay for the old. We analyze a political economy mechanism whereby the older are the native-born population the more likely is that the immigration policy is liberalized; which in turn has a positive effect on the sustainability of the social security system.

For this purpose we develop an OLG political economy model to explore how immigration policy and a pay-as-you-go (PAYG) social security system are jointly determined. The pay-as-you-go social security system employs payroll taxes on the working young in order to finance a social-security benefit to the aged. Immigrants enter the economy when young, and gain the right to vote only in the next period, when old. Except from having a higher population growth rate, they have the same preferences and contribute to and benefit from the welfare state in the same way as the native-born. Their offspring are assumed to be completely integrated into the country and have the same population growth as the native-born.

The model is a political economy model where the political decisions regarding labor taxation and immigration quotas are taken simultaneously, through majority voting. Markov sub-game perfect political equilibria of the game feature a dynamic of repeated voting where individuals are forward looking, in the sense that they take into account the effect of their current voting on the next period voting decisions. The Markov sub-game perfect equilibria depend on the state variables. When the immigration quotas is the only state variable, voters engage in a "demographic switching" strategy in the sense that under the assumption that immigrants gain the right to vote only in the next period when they are old, voters take into account the effect of admitting a certain number of immigrants on the composition of voters and their voting preferences in the next period. Moreover, when the number of young exceeds the number of old, the young, who is then the decisive voter, admits a limited number of immi-

grants, in order to manipulate next period decisive voter's identity, switching from young to old. In so doing the voter maximizes her next period benefits. 
When there is an additional state variable- the stock of capital per (native-born) worker, there is another channel of influence on next period political-economy policy variables. There can be another possible strategy of the young, a "demographic steady" strategy, where she chooses to admit the maximum amount of immigrant, and in so doing she renders a majority of young every period. In this case, both "demographic switching" and "demographic steady" strategies are incorporated creating a "combined strategy" equilibrium.

An interesting extension could be to introduce heterogeneity within the native-born and the immigrant's population in terms of labor productivity. This would bring into the current model intragenerational distribution aspects. In addition it would also create other possible types of representative voters i.e. old native-born/ immigrants and young native-born/ immigrants voters, which can create an interaction between fiscal leakages across income groups and young voter strategies.

\section{Appendix}

\subsection{Proposition I:}

Proof. We must show that the vector of policy decision rules, $\Psi=(T, G)$, as defined in the proposition, satisfies the equilibrium conditions:

1. $\widehat{\Psi}\left(\gamma_{t-1}\right)=\arg \max _{\pi_{t}} V^{i}\left(\gamma_{t-1}, \pi_{t}, \pi_{t+1}\right)$, subject to $\pi_{t+1}=\Psi\left(\gamma_{t}\right)$.

2. $\widehat{\Psi}\left(\gamma_{t-1}\right)=\Psi\left(\gamma_{t-1}\right)$.

If $u_{t} \geq 1$, then the decisive voter is old. Substituting for $l_{t}$ from equation (8) into (12), the utility of the old can be rewritten as:

$$
V^{o}\left(\gamma_{t-1}\right)=\frac{\tau_{t}\left(1-\tau_{t}\right)^{\frac{1}{\Psi}}\left[(1+n)+\gamma_{t-1}(1+m)\right]\left(1+\gamma_{t}\right)}{\left(1+\gamma_{t-1}\right)}
$$

It is straightforward to show that $V^{o}\left(\gamma_{t-1}\right)$ is maximized by setting $\pi_{t}=$ $\left(\frac{\Psi}{\Psi+1}, 1\right)$.

If $u_{t}<1$, then the decisive voter is young. From equation (9), the utility of the young voter subject to $\pi_{t+1}=\Psi\left(\gamma_{t}\right)$, is given by:

$V^{y}\left(\gamma_{t-1}\right)=\left\{\begin{array}{ccc}\log \left[\frac{\Psi}{\Psi+1}\left(1-\tau_{t}\right)^{\frac{\Psi+1}{\Psi}}\right] & \text { if } & u_{t+1}<1 \\ \log \left[\frac{\Psi}{\Psi+1}\left(1-\tau_{t}\right)^{\frac{\Psi+1}{\Psi}}\right]+\beta \log \left[\frac{2 \frac{\Psi}{\Psi+1}\left(1-\frac{\Psi}{\Psi+1}\right)^{\frac{1}{\Psi}}\left[1+n+\gamma_{t}(1+m)\right]}{\left(1+\gamma_{t}\right)}\right] & \text { otherwise }\end{array}\right.$

In that case $V^{y}\left(\gamma_{t-1}\right)$ is maximized by setting $\pi_{t}=\left(0,-\frac{n}{m}\right)$. It should be noted that in the case where the population growth rates are both positive, $m, n>0$, 
then for every immigration quota there is a majority of young in every period, and thus the young decisive voter in every period will be indifferent between all possible immigration quota levels.

\subsection{Proposition II:}

Proof. We must show that the vector of policy decision rules, $\Psi=(T, G)$, satisfies the following equilibrium conditions:

1. $\widehat{\Psi}\left(\gamma_{t-1}\right)=\arg \max _{\pi_{t}} V^{i}\left(\gamma_{t-1}, \pi_{t}, \pi_{t+1}\right)$, subject to $\pi_{t+1}=\Psi\left(\gamma_{t}\right)$.

2. $\widehat{\Psi}\left(\gamma_{t-1}\right)=\Psi\left(\gamma_{t-1}\right)$.

3. $S\left(\pi_{t}, k_{t}\right)=\frac{\beta}{1+\beta} \frac{\Psi}{\Psi+1} \frac{\left(1+\gamma_{t}\right) w_{t} l_{t}\left(1-\tau_{t}\right)\left(1-f\left(\tau_{t+1}\right)\right)}{1+n+\gamma_{t}(1+m)}$, with $\tau_{t+1}=T\left(\gamma_{t}\right)$.

Consider first the case where there is a majority of old in period $t$, i.e. $u_{t} \geq 1$. Using the fact that,

$$
\begin{gathered}
w_{t} l_{t}\left(1-\tau_{t}\right)=\left((1-\alpha) k_{t}^{\alpha}\left(1+\gamma_{t}\right)^{-\alpha}\left(1-\tau_{t}\right)\right)^{\frac{1+\Psi}{\Psi+\alpha}} \\
1+r_{t}=\alpha\left((1-\alpha) k_{t}^{-\Psi}\left(1+\gamma_{t}\right)^{\Psi}\left(1-\tau_{t}\right)\right)^{\frac{1-\alpha}{\Psi+\alpha}}
\end{gathered}
$$

the utility of the old voter can be rewritten as:

$$
\begin{aligned}
& V^{o}\left(\gamma_{t-1}, k_{t}\right)=\frac{\tau_{t}\left((1-a)\left(1+\gamma_{t}\right)^{-a} k_{t}^{\alpha}\right)^{\frac{1+\Psi}{\Psi+\alpha}}\left(1-\tau_{t}\right)^{\frac{1-\alpha}{\Psi+\alpha}}\left[(1+n)+\gamma_{t-1}(1+m)\right]\left(1+\gamma_{t}\right)}{\left(1+\gamma_{t-1}\right)} \\
& +\alpha\left((1-\alpha) k_{t}^{-\Psi}\left(1+\gamma_{t}\right)^{\Psi}\left(1-\tau_{t}\right)\right)^{\frac{1-\alpha}{\Psi+\alpha}} k_{t}\left(\frac{1+n+\gamma_{t-1}(1+m)}{\left(1+\gamma_{t-1}\right)}\right)
\end{aligned}
$$

It is can be proved that $V^{o}\left(\gamma_{t-1}, k_{t}\right)$ is maximized by setting $\pi_{t}=\left(\frac{\Psi}{\Psi+1}, 1\right)$.

Consider next the case where there is a majority of young in period $t$, i.e. $u_{t}<1$. Substituting for $w_{t} l_{t}\left(1-\tau_{t}\right)$ and $1+r_{t+1}$ from equations (39) and (40), the utility of the young voter subject to: $\pi_{t+1}=\Psi\left(\gamma_{t}\right)$, can be written in the Lagrangian form, in the following way:

$$
L=\left\{\begin{array}{ccc}
L\left(k_{t}\right) \text { with } \pi_{t+1}=\left(0, \operatorname{Min}\left[\gamma^{*},-\frac{n}{m}\right]\right) & \text { if } & u_{t+1}<1 \\
L\left(k_{t}\right) \text { with } \pi_{t+1}=\left(\frac{\Psi}{\Psi+1}, 1\right) & \text { otherwise } &
\end{array}\right.
$$

where $A=(1+\beta) \log \left(\frac{1}{1+\beta} \frac{\Psi}{\Psi+1}\right)+\beta \log (\beta), \lambda_{1}$ is the Lagrangian multiplier, and $L\left(k_{t}\right)$ is defined as follows:

$$
L\left(k_{t}\right)=\left\{\begin{array}{c}
A+(1+\beta) \log \left[\left((1-\alpha) k_{t}^{\alpha}\left(1+\gamma_{t}\right)^{-\alpha}\left(1-\tau_{t}\right)\right)^{\frac{1+\Psi}{\Psi+\alpha}}\left(1+\beta f\left(\tau_{t+1}\right)\right]\right. \\
+\beta \log \left(\alpha(1-\alpha) k_{t+1}^{-\Psi}\left(1+\gamma_{t+1}\right)^{\Psi}\left(1-\tau_{t+1}\right)\right)^{\frac{1-\alpha}{\Psi+\alpha}} \\
-\lambda_{1}\left(k_{t+1}-\frac{\beta}{1+\beta} \frac{\Psi}{\Psi+1} \frac{\left(1+\gamma_{t}\right)\left((1-\alpha) k_{t}^{\alpha}\left(1+\gamma_{t}\right)^{-\alpha}\left(1-\tau_{t}\right)\right)^{\frac{1+\Psi}{\Psi+\alpha}}\left(1-f\left(\tau_{t+1}\right)\right.}{1+n+\gamma_{t}(1+m)}\right)
\end{array}\right.
$$


As a first step, it is easy to prove that the indirect utility of the young subject to constant next period policy variables, is maximized by setting: $\pi_{t}=\left(0, \gamma^{*}\right)$, where $\gamma^{*} \in[0,1]$ is defined as follows:

$$
\gamma^{*}=\frac{\beta(1-\alpha) \Psi(n-m)+\alpha(1+\Psi)(1+n) x}{-\alpha(1+\Psi)(1+m) x}
$$

We will prove that in the case where $m+n>0$ and $n<0$, the indirect utility of the young $V^{y}\left(\gamma_{t-1}, k_{t}\right)$ is maximized by $\pi_{t}=\left(0, \operatorname{Min}\left[\gamma^{*},-\frac{n}{m}\right]\right)^{8}$. If $\gamma^{*} \leq-\frac{n}{m}$, then it is sufficient to prove that the indirect utility of the young is higher by setting $\pi_{t+1}=\left(\frac{\Psi}{\Psi+1}, 1\right)$ than by setting $\pi_{t+1}=\left(0, \gamma^{*}\right)$. It is easy to see that the higher is next period immigration quota the higher is the indirect utility of the young since it increases next period interest rate. Regarding the next period tax rate, it is sufficient to prove that:

$$
0=\log \left[(1+\beta f(0))^{1+\beta}\right] \leq \log \left[\left(1+\beta f\left(\frac{\Psi}{\Psi+1}\right)\right)^{1+\beta}\left(1-\frac{\Psi}{\Psi+1}\right)^{\beta \frac{1-\alpha}{\Psi+\alpha}}\right]
$$

due to the fact that the following holds,

$$
0=\log \left[(1-f(0))^{-\Psi \beta \frac{1-\alpha}{\Psi+\alpha}}\right] \leq \log \left[\left(1-f\left(\frac{\Psi}{\Psi+1}\right)\right)^{-\Psi \beta \frac{1-\alpha}{\Psi+\alpha}}\right]
$$

Define the function: $d(\Psi)=\log \left[\left(1+\beta f\left(\frac{\Psi}{\Psi+1}\right)\right)^{1+\beta}\left(1-\frac{\Psi}{\Psi+1}\right)^{\beta \frac{1-\alpha}{\Psi+\alpha}}\right]$. The derivative of $d(\Psi)$ is the following expression:

$$
\left(\frac{1}{\Psi+1}\right)^{\frac{\Psi+\alpha+\beta-\alpha \beta}{\Psi+\alpha}}\left(\begin{array}{c}
(\alpha-1) \beta(1+\beta)^{2}\left(\frac{(\Psi+\alpha)(1+\beta)}{\Psi+\alpha+\beta+\alpha \beta+\alpha \beta \Psi}\right)^{\beta-1} \\
\frac{\left(\Psi(1-\alpha)(\Psi+\alpha)+(\Psi+1)(\Psi+\alpha+\beta+\alpha \beta+\alpha \beta \Psi) \log \left(\frac{1}{\Psi+1}\right)\right)}{(\Psi+\alpha+\beta+\alpha \beta+\alpha \beta \Psi)^{2}}
\end{array}\right)
$$

Since this derivative is positive for every $\Psi>0$, and for $\Psi=0$ the function is equal to zero $(d(\Psi=0)=0)$, then $d(\Psi)$ is positive for every $\Psi>0$.

Otherwise, if $\gamma^{*}>-\frac{n}{m}$, we must prove that the following holds,

$$
\begin{gathered}
\log \left(\left(1+\gamma^{*}\right)^{-\alpha}\right)^{\frac{1+\Psi}{\Psi+\alpha}(1+\beta)}+\log \left(\left(\frac{\left(1+\gamma^{*}\right)\left(\left(1+\gamma^{*}\right)^{-\alpha}\right)^{\frac{1+\Psi}{\Psi+\alpha}}}{1+n+\gamma^{*}(1+m)}\right)^{-\Psi}\left(1-\frac{n}{m}\right)^{\Psi}\right)^{\beta \frac{1-\alpha}{\Psi+\alpha}} \\
\leq(1+\beta) \log \left[\left(1-\frac{n}{m}\right)^{-\alpha \frac{1+\Psi}{\Psi+\alpha}}\left(1+\beta f\left(\frac{\Psi}{\Psi+1}\right)\right]+\right. \\
\log \left(\left(\frac{\left(1-\frac{n}{m}\right)\left(\left(1-\frac{n}{m}\right)^{-\alpha}\right)^{\frac{1+\Psi}{\Psi+\alpha}}\left(1-f\left(\frac{\Psi}{\Psi+1}\right)\right.}{1+n-\frac{n}{m}(1+m)}\right)^{-\Psi} 2^{\Psi}\left(1-\frac{\Psi}{\Psi+1}\right)\right)^{\beta \frac{1-\alpha}{\Psi+\alpha}}
\end{gathered}
$$

\footnotetext{
${ }^{8}$ If the population growth rates are both positive, $m, n>0$, then it is straightforward to see that $V^{y}\left(\gamma_{t-1}, k_{t}\right)$ is maximized by $\pi_{t}=\left(0, \operatorname{Min}\left[\gamma^{*},-\frac{n}{m}\right]\right)$.
} 
Since as was proved $d(\Psi)$ is positive for every $\Psi>0$, and for $\gamma^{*}>-\frac{n}{m}$, the following holds,

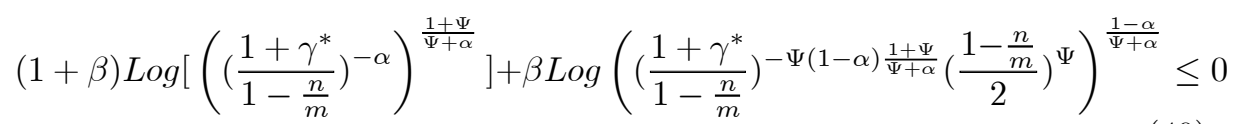

it is sufficient to prove that,

$$
\beta \log \left(\frac{1+n-\frac{n}{m}(1+m)}{1+n+\gamma^{*}(1+m)}\right)^{-\Psi \frac{1-\alpha}{\Psi+\alpha}} \leq \beta \log \left(1-f\left(\frac{\Psi}{\Psi+1}\right)\right)^{-\Psi \frac{1-\alpha}{\Psi+\alpha}}
$$

Substituting $\gamma^{*}$ from equation (44) into equation (50), we can rewrite the inequality in the following way,

$$
\left(1+\frac{1-\alpha}{\alpha} \frac{1}{1+\beta} \frac{\Psi}{\Psi+1}\right) \geq \frac{\beta(1-\alpha) \Psi}{\alpha(1+\Psi) x \frac{1}{m}}
$$

Since this expression is positive, it completes the proof that $V^{y}\left(\gamma_{t-1}, k_{t}\right)$ is maximized by setting $\pi_{t}=\left(0, \operatorname{Min}\left[\gamma^{*},-\frac{n}{m}\right]\right)$.

\subsection{Proposition III:}

Proof. The proof will consist of two parts. The first part will prove that when there is a majority of young voters the policy decisions for the tax rate and immigration quotas stated maximizes the young indirect utility function, under the assumption that next period decisive voter is young. The second part will complete the proof and show that under certain conditions on the models parameters, the vector of policy decision rules as defined in the proposition, satisfies the equilibrium conditions.

\section{The first part of the proof:}

We follow the proof of Forni (2004) to derive the policy decision rules. The policy decision rules are obtained by using as a constraint the first derivative with respect to the policy variables of the logarithm of the capital accumulation equation. The policy decision rules are the following:

$$
\begin{gathered}
\left(1+\frac{1-\alpha}{\alpha} \tau_{t}\left(k_{t}\right)\right)^{1+\beta}\left(1-\tau_{t}\left(k_{t}\right)\right)^{\frac{\beta(1-\alpha)}{\Psi+\alpha}}=k_{t}^{-x} c \\
\gamma_{t}=1
\end{gathered}
$$

where $x=1+\frac{(1+\Psi) \alpha \beta}{\Psi+\alpha}$, and $c$ is a positive constant of integration. The policy decision rule of the immigration quotas is at its maximal value, and the policy decision rule of the tax rate is implicitly given in equation (52). Define the 
following function: $F(\tau)=\left(\left(1+\frac{1-\alpha}{\alpha} \tau\right)^{1+\beta}(1-\tau)^{\frac{\beta(1-\alpha)}{\alpha+\Psi}} \frac{1}{c}\right)^{-\frac{1}{x}}$, thus we can rewrite the policy decision rule of the tax rate as: $F\left(\tau_{t}\right)=k_{t}$. The function $F(\tau)$ is decreasing in $\tau$, for $\tau \in[0, \bar{\tau}]$, where $\bar{\tau}=\frac{\Psi(1+\beta)+\alpha}{\Psi(1+\beta)+\alpha+\beta}$, and increasing in $\tau$, for $\tau \in[\bar{\tau}, 1]$. Thus, according to equation (52), for every value of capital per (native-born) worker, $k_{t}$, there are two solutions for $\tau\left(k_{t}\right)$ in the range $[0,1)$. The solution which satisfies the equilibrium conditions, which is denoted by $\tau\left(k_{t}\right)$, is decreasing in $k_{t}$ for $k_{t} \in[F(\bar{\tau}), F(0)]$.

The solution for the policy variables given in equations (52) and (53), will be proved to satisfy the first order conditions of the problem. Substituting for $w_{t} l_{t}\left(1-\tau_{t}\right)$ and $1+r_{t+1}$ from equations (39) and (40), the young voter's indirect utility function under the assumption that next period decisive voter is young, which sets next period policy decision rules for the tax rate and immigration quotas to be $\tau_{t+1}=\tau\left(k_{t+1}\right)$, and $\gamma_{t+1}=1$ respectively, can be written in its Lagrangian form as follows:

$$
\begin{aligned}
& L\left(k_{t}\right)=A+(1+\beta) \log \left((1-\alpha) k_{t}^{\alpha}\left(1+\gamma_{t}\right)^{-\alpha}\left(1-\tau_{t}\right)\right)^{\frac{1+\Psi}{\Psi+\alpha}}+ \\
& (1+\beta) \log \left[\left(1+\beta f\left(\tau\left(k_{t+1}\right)\right)+\beta \log \alpha\left((1-\alpha) k_{t+1}^{-\Psi} 2^{\Psi}\left(1-\tau\left(k_{t+1}\right)\right)\right)^{\frac{1-\alpha}{\Psi+\alpha}}\right.\right. \\
& -\lambda_{1}\left(k_{t+1}-\frac{\beta}{1+\beta} \frac{\Psi}{\Psi+1} \frac{\left(1+\gamma_{t}\right)\left((1-\alpha) k_{t}^{\alpha}\left(1+\gamma_{t}\right)^{-\alpha}\left(1-\tau_{t}\right)\right)^{\frac{1}{\Psi+\Psi}}\left(1-f\left(\tau\left(k_{t+1}\right)\right)\right.}{1+n+\gamma_{t}(1+m)}\right) \\
& -\lambda_{2}\left(\tau_{t}-1\right)-\lambda_{3}\left(-\tau_{t}\right)-\lambda_{4}\left(\gamma_{t}-1\right)-\lambda_{5}\left(\gamma_{t}\right)
\end{aligned}
$$

The Kuhn-Tucker conditions are:

$$
\begin{gathered}
\frac{\partial L}{\partial \tau_{t}}=0=-\frac{1+\Psi}{\Psi+\alpha} \frac{1+\beta}{1-\tau_{t}}-\lambda_{1} \frac{1+\Psi}{\Psi+\alpha} \frac{k_{t+1}}{1-\tau_{t}}-\lambda_{2}+\lambda_{3} \\
\frac{\partial L}{\partial \gamma_{t}}=0=-\alpha \frac{1+\Psi}{\Psi+\alpha} \frac{1+\beta}{1+\gamma_{t}}+\lambda_{1} \frac{k_{t+1}}{1+\gamma_{t}}\left(\frac{n-m}{1+n+\gamma_{t}(1+m)}-\alpha \frac{1+\Psi}{\Psi+\alpha}\right)-\lambda_{4}+\lambda_{5} \\
\frac{\partial L}{\partial k_{t+1}}=0=\left(\frac{\beta(1+\beta)}{1+\beta f\left(\tau\left(k_{t+1}\right)\right)}-\frac{\lambda_{1} k_{t+1}}{1-f\left(\tau\left(k_{t+1}\right)\right)}\right) \frac{\partial f\left(\tau_{t+1}\right)}{\partial \tau_{t+1}} \frac{\partial \tau\left(k_{t+1}\right)}{\partial k_{t+1}}(57) \\
-\frac{\beta(1-\alpha)}{\Psi+\alpha} \frac{1}{1-\tau\left(k_{t+1}\right)} \frac{\partial \tau\left(k_{t+1}\right)}{\partial k_{t+1}}+\frac{1}{k_{t+1}}\left(-\beta \frac{\Psi(1-\alpha)}{\Psi+\alpha}\right)-\lambda_{1} \\
k_{t+1}=\frac{\beta}{1+\beta} \frac{\Psi}{\Psi+1} \frac{\left(1+\gamma_{t}\right) w_{t} l_{t}\left(1-\tau_{t}\right)\left(1-f\left(\tau\left(k_{t+1}\right)\right)\right.}{1+n+\gamma_{t}(1+m)} \\
\tau_{t}-1 \leq 0, \lambda_{2} \geq 0 \text { and } \lambda_{2}\left(\tau_{t}-1\right)=0 \\
-\tau_{t} \leq 0, \lambda_{3} \geq 0 \text { and } \lambda_{3}\left(-\tau_{t}\right)=0 \\
\gamma_{t}-1 \leq 0, \lambda_{4} \geq 0 \text { and } \lambda_{4}\left(\gamma_{t}-1\right)=0 \\
-\gamma_{t} \leq 0, \lambda_{5} \geq 0 \text { and } \lambda_{5}\left(\gamma_{t}\right)=0
\end{gathered}
$$


Substituting for $\lambda_{1}$ from equation (57) into equations (55) and (56), we derive the following equations:

$$
\begin{gathered}
\frac{\partial L}{\partial \tau_{t}}=-\lambda_{2}+\lambda_{3}=0 \\
\frac{\partial L}{\partial \gamma_{t}}=\frac{(1+\beta)}{1+\gamma_{t}}\left(\frac{-n+m}{1+n+\gamma_{t}(1+m)}\right)-\lambda_{4}+\lambda_{5}=0
\end{gathered}
$$

Since we have assumed that $m>n$ from equation (64) we derive that $\gamma_{t}$ has a corner solution. The solution for the tax rate, on the other hand, $\tau_{t}$, may be bounding or not, meaning that $\tau_{t}=\tau\left(k_{t}\right) \in[0,1]^{9}$. Substituting the solutions for the tax and openness rate into the indirect utility of the young, we obtain that the optimal solution for the openness rate is $\gamma_{t}=1$.

The optimal solutions should also satisfy the second order sufficient condition, meaning that the bordered Hessian of the Lagrangian should be negatively defined. Since the solution of the immigration quotas is a corner solution where the largest immigration quota maximizes the young voter's indirect utility function, the bordered Hessian of the Lagrangian is equal to:

$$
-g_{\tau}\left(g_{\tau} \frac{\partial^{2} L}{\partial^{2} k_{t+1}}-g_{k} \frac{\partial^{2} L}{\partial k_{t+1} \partial \tau_{t}}\right)+g_{k}\left(g_{\tau} \frac{\partial^{2} L}{\partial \tau_{t} \partial k_{t+1}}-g_{k} \frac{\partial^{2} L}{\partial^{2} \tau_{t}}\right)
$$

where $g_{\tau}$ and $g_{k}$ are the derivatives of the constraint of the capital per (nativeborn) worker from equation (58) with respect to $\tau_{t}$ and $k_{t+1}$ respectively. The bordered Hessian can be rewritten in the following way:

$$
\begin{aligned}
& \left(\frac{1+\Psi}{\Psi+\alpha}\right)^{2} \frac{1}{\left(1-\tau_{t}\right)^{2}} \frac{2 x\left(1+\frac{1-\alpha}{\alpha} \tau_{t}\right)\left(1-\tau_{t}\right)\left(\frac{1-\alpha}{\alpha}\right)}{\left((1+\beta) \frac{1-\alpha}{\alpha}\left(1-\tau_{t}\right)-\frac{\beta(1-\alpha)}{\Psi+\alpha}\left(1+\frac{1-\alpha}{\alpha} \tau_{t}\right)\right)^{2}\left(1+\frac{1-\alpha}{\alpha} \frac{1}{1+\beta} \tau_{t}\right)^{2}} \\
& \left(\begin{array}{c}
x\left(1+\frac{1-\alpha}{\alpha} \tau_{t}\right)\left(1-\tau_{t}\right)\left(\frac{1-\alpha}{\alpha}\right)+ \\
\left((1+\beta) \frac{1-\alpha}{\alpha}\left(1-\tau_{t}\right)-\frac{\beta(1-\alpha)}{\Psi+\alpha}\left(1+\frac{1-\alpha}{\alpha} \tau_{t}\right)\right)\left(1+\frac{1-\alpha}{\alpha} \frac{1}{1+\beta} \tau_{t}\right)(1+\beta)
\end{array}\right)
\end{aligned}
$$

Denote by $\left[\tau_{1}, \tau_{2}\right]$ the range of the tax rate for which the bordered Hessian of the Lagrangian is negatively defined. The optimal solution for the tax rate, $\tau\left(k_{t}\right)$, is in the range $k_{t} \in\left[F\left(\bar{\tau}_{1}\right), F\left(\tau_{1}\right)\right]$, where the function $F(\tau)$ is decreasing in $\tau$.

\section{The second part of the proof:}

As in the proposition II, we must show that the vector of policy decision rules, $\Psi=(T, G)$, satisfies the equilibrium conditions (the only difference is that the policy decision rules, $\Psi\left(\gamma_{t-1}, k_{t}\right)$, depend not only on the previous immigration policy but also on the current capital per (native born) worker).

\footnotetext{
${ }^{9}$ Note that the utility with $\tau_{t}=1$ is equal to minus infinity. Thus, the range for the tax rate is $[0,1)$.
} 
If the population growth rates satisfy the properties: $m+n>0$ and $n<0$.

Consider first the case where there is a majority of old in period $t$, i.e. $u_{t} \geq 1$. The utility of the old voter is the same as in the previous proposition and thus $V^{o}\left(\gamma_{t-1}, k_{t}\right)$ is maximized by setting: $\pi_{t}=\left(\frac{\Psi}{\Psi+1}, 1\right)$. But unlike the previous proposition the saving of the young in period $t$ also depends on next period policy variables. Thus, for $k_{t} \in\left[g\left(F\left(\bar{\tau}_{1}\right)\right), g\left(F\left(\tau_{1}\right)\right)\right]$, the aggregate saving decision rule should follow: $S\left(k_{t}, \pi_{t}=\left(\frac{\Psi}{\Psi+1}, 1\right), \tau_{t+1}=\tau\left(k_{t+1}\right)\right)$. Otherwise, the aggregate saving decision rule should follow: $S\left(k_{t}, \pi_{t}=\left(\frac{\Psi}{\Psi+1}, 1\right), \tau_{t+1}=0\right)$. Since the derivative of next period capital per (native born) worker (defined according to the first aggregate saving decision rule) by $k_{t}$ can be either negative or positive, the first condition will require that the derivative will be positive, meaning that the tax rate should be in the range $\tau \in\left[\tau_{1}, \bar{\tau}_{1}\right] \subseteq\left[\tau_{1}, \bar{\tau}\right]$, where $\bar{\tau}_{1}=\frac{\Psi}{\Psi+1}$. Denote by $g(y): k_{t+1}->k_{t}$ the following function:

$g(y)=\left(\left(\frac{\beta}{1+\beta} \frac{\Psi}{\Psi+1} \frac{2}{2+n+m}(1-f(\tau(y)))\left((1-\alpha) 2^{-\alpha}\left(1-\frac{\Psi}{\Psi+1}\right)\right)^{\frac{1+\Psi}{\Psi+\alpha}}\right)^{-1} y\right)^{\frac{\Psi+\alpha}{\alpha(1+\Psi)}}$

Thus, for $k_{t} \in\left[g\left(F\left(\bar{\tau}_{1}\right)\right), g\left(F\left(\tau_{1}\right)\right)\right]$, next period policy variables are set according to: $\pi_{t+1}=\left(\tau\left(k_{t+1}\right), 1\right)$ and the aggregate saving decision rule follows: $S\left(k_{t}, \pi_{t}=\left(\frac{\Psi}{\Psi+1}, 1\right), \tau_{t+1}=\tau\left(k_{t+1}\right)\right)$. Note that for $k_{t} \in\left[g\left(F\left(\bar{\tau}_{1}\right)\right), g\left(F\left(\tau_{1}\right)\right)\right]^{c}$ the decision rule of the tax rate $\tau_{t}\left(k_{t}\right)$ is outside the relevant range, $\left[\tau_{1}, \bar{\tau}_{1}\right]$. Therefore the solution would imply setting the constrained, meaning either $\tau=\tau_{1}$ or $\tau=\bar{\tau}_{1}$. The required condition is that setting the constrained would yield the aggregate saving decision rule: $S\left(k_{t}, \pi_{t}=\left(\frac{\Psi}{\Psi+1}, 1\right), \tau_{t+1}=0\right)$.

Consider next the case where there is a majority of young in period $t$, i.e. $u_{t}<1$. If $k_{t} \in\left[F\left(\bar{\tau}_{1}\right), F\left(\tau_{1}\right)\right]$, we must prove that the indirect utility of the young voter is maximized by the "demographic steady" strategy, meaning: $\pi_{t}=\Psi\left(\tau\left(k_{t}\right), 1\right)$ and the aggregate saving decision rule follows: $S\left(k_{t}, \pi_{t}=\right.$ $\left.\left(\tau\left(k_{t}\right), 1\right), \tau_{t+1}=\tau\left(k_{t+1}\right)\right)$. Otherwise, If $k_{t} \in\left[F\left(\bar{\tau}_{1}\right), F\left(\tau_{1}\right)\right]^{c}$, we must prove that the indirect utility of the young voter is maximized by the "demographic switching" strategy, meaning: $\pi_{t}=\left(0, \operatorname{Min}\left[\gamma^{*},-\frac{n}{m}\right]\right)$ and the aggregate saving decision rule follows: $S\left(k_{t}, \pi_{t}=\left(0, \operatorname{Min}\left[\gamma^{*},-\frac{n}{m}\right]\right), \tau_{t+1}=\frac{\Psi}{\Psi+1}\right)$. Substituting for $w_{t} l_{t}\left(1-\tau_{t}\right)$ and $1+r_{t+1}$ from equations (39) and (40), the young voter's indirect utility function, can be written in its Lagrangian form as follows:

$$
\begin{aligned}
& L= \\
& \left\{\begin{array}{cccc}
L\left(k_{t}\right) \text { with } \pi_{t+1}=\left(\tau\left(k_{t+1}\right), 1\right) \quad \text { if } \quad k_{t+1} \in\left[F\left(\bar{\tau}_{1}\right), F\left(\tau_{1}\right)\right] & \text { if } & u_{t+1}<1 \\
L\left(k_{t}\right) \text { with } \pi_{t+1}=\left(0, \operatorname{Min}\left[\gamma^{*},-\frac{n}{m}\right]\right) \quad \text { otherwise } & \text { otherwise }
\end{array}\right.
\end{aligned}
$$


where $L\left(k_{t}\right)$ is as defined in equation (43). The first part of this proposition, proved that if next period decision rules are set according to the "demographic steady" strategy, and the capital per (native-born) worker is in the range: $\left[F\left(\bar{\tau}_{1}\right), F\left(\tau_{1}\right)\right]$, then the optimal solution for the young is $\pi_{t}=\left(\tau\left(k_{t}\right), 1\right)$. In addition, we have shown in proposition II, that under the assumption that next period policy decision rules are given according to:

$$
\pi_{t+1}=\left\{\begin{array}{ccc}
\left(0, \operatorname{Min}\left[\gamma^{*},-\frac{n}{m}\right]\right) & \text { if } & u_{t+1}<1 \\
\left(\frac{\Psi}{\Psi+1}, 1\right) & \text { otherwise } &
\end{array}\right.
$$

the young voter's indirect utility function is maximized by the "demographic switching" strategy: $\pi_{t}=\left(0, \operatorname{Min}\left[\gamma^{*},-\frac{n}{m}\right]\right)$. Therefore we must show that if $k_{t} \in\left[F\left(\bar{\tau}_{1}\right), F\left(\tau_{1}\right)\right]$, the value of the young voter's indirect utility function is higher under the "demographic steady" strategy. Since the value of the young voter's indirect utility function under the "demographic steady" strategy is constant in $k_{t} \in\left[F\left(\bar{\tau}_{1}\right), F\left(\tau_{1}\right)\right]$, and the value of the young voter's indirect utility function under the "demographic switching" strategy is increasing in $k_{t}$, the value of the young voter's indirect utility function under the "demographic steady" strategy must not be lower than the "demographic switching" strategy for $k_{t}=F\left(\tau_{1}\right)$ :

$$
\begin{gathered}
\log \left(\left(\frac{2}{2+n+m} \frac{\beta}{1+\beta} \frac{\Psi}{\Psi+1}\right)^{-(1+\beta)} 2^{\frac{\Psi \beta(1-\alpha)}{\Psi+\alpha}} c\right) \geq \\
(1+\beta) \log \left(\left((1-\alpha) F\left(\tau_{1}\right)^{\alpha}\left(1+\gamma_{t}\right)^{-\alpha}\right)^{\frac{1+\Psi}{\Psi+\alpha}}\left(1+\beta f\left(\frac{\Psi}{\Psi+1}\right)\right)+\right. \\
\log \left(\alpha\left((1-\alpha)\left(1-\frac{\Psi}{\Psi+1}\right) 2^{\Psi}\left(\frac{\beta}{1+\beta} \frac{\Psi}{\Psi+1} \frac{\left(1+\gamma_{t}\right)\left((1-\alpha) F\left(\tau_{1}\right)^{\alpha}\left(1+\gamma_{t}\right)^{-\alpha}\right)^{\frac{1+\Psi}{\Psi+\alpha}}\left(1-f\left(\frac{\Psi}{\Psi+1}\right)\right.}{1+n+\gamma_{t}(1+m)}\right)^{-\Psi}\right)^{\frac{1-\alpha}{\Psi+\alpha}}\right)^{\beta}
\end{gathered}
$$

In addition, we must require that if $k_{t} \in\left[F\left(\bar{\tau}_{1}\right), F\left(\tau_{1}\right)\right]$, then also the aggregate saving decision rule, $S\left(k_{t}, \pi_{t}=\left(\tau\left(k_{t}\right), 1\right), \tau_{t+1}=\tau\left(k_{t+1}\right)\right) \in\left[F\left(\bar{\tau}_{1}\right), F\left(\tau_{1}\right)\right]$. The derivative of next period capital per (native born) worker (defined according to this aggregate saving decision rule) by $k_{t}$ is positive for $k_{t} \in\left[F\left(\bar{\tau}_{1}\right), F\left(\tau_{1}\right)\right]$. Denote by $h^{1}(y)$ and $h^{2}(y)$ the following functions:

$$
\begin{aligned}
& h^{1}(y)=y-\frac{\beta}{1+\beta} \frac{\Psi}{\Psi+1} \frac{2}{2+n+m}\left((1-\alpha)\left(F\left(\bar{\tau}_{1}\right)\right)^{\alpha} 2^{-\alpha}\left(1-\bar{\tau}_{1}\right)\right)^{\frac{1+\Psi}{\Psi+\alpha}}(1-f(\tau(y))) \\
& h^{2}(y)=y-\frac{\beta}{1+\beta} \frac{\Psi}{\Psi+1} \frac{2}{2+n+m}\left((1-\alpha)\left(F\left(\tau_{1}\right)\right)^{\alpha} 2^{-\alpha}\left(1-\tau_{1}\right)\right)^{\frac{1+\Psi}{\Psi+\alpha}}(1-f(\tau(y)))
\end{aligned}
$$

Denote by $\underline{k}_{1}, \bar{k}_{1} \in\left[F\left(\bar{\tau}_{1}\right), F\left(\tau_{1}\right)\right]$, the solutions of equations: $h^{2}\left(\bar{k}_{1}\right)=0$ and $h^{1}\left(\underline{k}_{1}\right)=0$ respectively. Thus, the required condition is that $\left[\underline{k}_{1}, \bar{k}_{1}\right] \subseteq$ 
[F( $\left.\left.\bar{\tau}_{1}\right), F\left(\tau_{1}\right)\right]$. Under this condition, if $k_{t} \in\left[F\left(\bar{\tau}_{1}\right), F\left(\tau_{1}\right)\right]$, the indirect utility of the young voter is maximized by the "demographic steady" strategy and the aggregate saving decision rule follows: $S\left(k_{t}, \pi_{t}=\left(\tau\left(k_{t}\right), 1\right), \tau_{t+1}=\tau\left(k_{t+1}\right)\right) \in$ $\left[F\left(\bar{\tau}_{1}\right), F\left(\tau_{1}\right)\right]$. For $k_{t} \in\left[F\left(\bar{\tau}_{1}\right), F\left(\tau_{1}\right)\right]^{c}$, the value of the young voter's indirect utility function is not lower under the "demographic switching" strategy than under the "demographic steady" strategy (since for $\tau_{t} \in\left[\tau_{1}, \bar{\tau}_{1}\right]^{c}$, the solution would imply setting the constrained). Thus, if $k_{t} \in\left[F\left(\bar{\tau}_{1}\right), F\left(\tau_{1}\right)\right]^{c}$, the indirect utility of the young voter is maximized according to the "demographic switching" strategy: $\pi_{t}=\left(0, \operatorname{Min}\left[\gamma^{*},-\frac{n}{m}\right]\right)$ and the aggregate saving decision rule follows: $S\left(k_{t}, \pi_{t}=\left(0, \operatorname{Min}\left[\gamma^{*},-\frac{n}{m}\right]\right), \tau_{t+1}=\frac{\Psi}{\Psi+1}\right)$. It should be noted that since the optimal solution changes next period decisive voter from young to old, for all values of $k_{t+1}$ (defined according to this aggregate saving decision rule: $\left.S\left(k_{t}, \pi_{t}=\left(0, \operatorname{Min}\left[\gamma^{*},-\frac{n}{m}\right]\right), \tau_{t+1}=\frac{\Psi}{\Psi+1}\right)\right)$, there are no additional conditions on $k_{t+1}$. These conditions are sufficient to assure that the equilibrium conditions are satisfied when: $m+n>0$ and $n<0$.

If the population growth rates satisfy the properties: $n, m>0$, there is a majority of young in every period.

If $k_{t} \in\left[F\left(\bar{\tau}_{1}\right), F\left(\tau_{1}\right)\right]$, we must prove that the indirect utility of the young voter is maximized by setting: $\Psi\left(\tau\left(k_{t}\right), 1\right)$ and the aggregate saving decision rule follows: $S\left(k_{t}, \pi_{t}=\left(\tau\left(k_{t}\right), 1\right), \tau_{t+1}=\tau\left(k_{t+1}\right)\right)$. Otherwise, If $k_{t} \in\left[F\left(\bar{\tau}_{1}\right), F\left(\tau_{1}\right)\right]^{c}$, we must prove that the indirect utility of the young voter is maximized by setting: $\pi_{t}=\left(0, \gamma^{*}\right)$ and the aggregate saving decision rule follows: $S\left(k_{t}, \pi_{t}=\right.$ $\left.\left(0, \gamma^{*}\right), \tau_{t+1}=0\right)$. The young voter's indirect utility function can be written in its Lagrangian form as follows:

$$
L=\begin{array}{ll}
L\left(k_{t}\right) \text { with } \pi_{t+1}=\left(\tau\left(k_{t+1}\right), 1\right) & \text { if } \quad k_{t+1} \in\left[F\left(\bar{\tau}_{1}\right), F\left(\tau_{1}\right)\right] \\
L\left(k_{t}\right) \text { with } \pi_{t+1}=\left(0, \gamma^{*}\right) & \text { otherwise }
\end{array}
$$

where $L\left(k_{t}\right)$ is as defined in equation (43). Note that the immigration quota is not restricted $\left(\gamma_{t}=\gamma^{*}\right)$, since the young decisive voter cannot change next period decisive voter from young to old. According to proposition II, the indirect utility of the young subject to constant next period policy variables, is maximized by setting: $\pi_{t}=\left(0, \gamma^{*}\right)$. Thus, similarly to the previous case, we will require that the value of the young voter's indirect utility function under the first decision rule $\left(\pi_{t}=\left(\tau\left(k_{t}\right), 1\right)\right)$, should not be lower than the value of the young voter's indirect utility function under the second decision rule $\left(\pi_{t}=\Psi\left(0, \gamma^{*}\right)\right)$ 
at $k_{t}=F\left(\tau_{1}\right)$ :

$$
\begin{gathered}
\log \left(\left(\frac{2}{2+n+m} \frac{\beta}{1+\beta} \frac{\Psi}{\Psi+1}\right)^{-(1+\beta)} 2^{\frac{\Psi \beta(1-\alpha)}{\Psi+\alpha} c} c\right) \geq \\
(1+\beta) \log \left(\left((1-\alpha) F\left(\tau_{1}\right)^{\alpha}\left(1+\gamma^{*}\right)^{-\alpha}\right)^{\frac{1+\Psi}{\Psi+\alpha}}\right)+ \\
\log \left(\alpha\left((1-\alpha)\left(1+\gamma^{*}\right)^{\Psi}\left(\frac{\beta}{1+\beta} \frac{\Psi}{\Psi+1} \frac{\left(1+\gamma^{*}\right)\left((1-\alpha) F\left(\tau_{1}\right)^{\alpha}\left(1+\gamma^{*}\right)^{-\alpha}\right)^{\frac{1+\Psi}{\Psi+\alpha}}}{1+n+\gamma^{*}(1+m)}\right)^{-\Psi}\right)^{\frac{1-\alpha}{\Psi+\alpha}}\right)^{\beta}
\end{gathered}
$$

The same conditions as before are required, meaning that $\left[\underline{k}_{1}, \bar{k}_{1}\right] \subseteq\left[F\left(\bar{\tau}_{1}\right), F\left(\tau_{1}\right)\right]$. But, unlike the previous case, when $k_{t} \in\left[F\left(\bar{\tau}_{1}\right), F\left(\tau_{1}\right)\right]^{c}$, the optimal strategy do not change next period decisive voter from young to old. Therefore we will additionally require that for $k_{t} \in\left[F\left(\bar{\tau}_{1}\right), F\left(\tau_{1}\right)\right]^{c}$, the value of the young voter's indirect utility function under the corner solutions of the first decision rule will be lower (or equal) to the value of the young voter's indirect utility function under the second decision rule, and that the aggregate saving decision rule follows: $S\left(k_{t}, \pi_{t}=\left(0, \gamma^{*}\right), \tau_{t+1}=0\right)$. Since for $k_{t} \in\left[F\left(\bar{\tau}_{1}\right), F\left(\tau_{1}\right)\right]^{c}$, the decision rule of the tax rate $\tau_{t}\left(k_{t}\right)$ is a corner solution, the solution would imply setting the constrained, meaning $\tau=\tau_{1}$ or $\tau=\bar{\tau}_{1}$. Therefore the required condition is that setting the constrained would yield that the value of the young voter's indirect utility function under the corner solutions of the first decision rule is lower (or equal) and that the aggregate saving decision rule follows: $S\left(k_{t}, \pi_{t}=\left(0, \gamma^{*}\right), \tau_{t+1}=0\right)$. These conditions are sufficient to assure that the equilibrium conditions are satisfied when: $n>0$.

If the population growth rates satisfy the property: $n+m<0$, there is a majority of old in every period. It is straightforward to see that the old decisive voter's utility $V^{o}\left(\gamma_{t-1}, k_{t}\right)$ is maximized by setting $\pi_{t}=\left(\frac{\Psi}{\Psi+1}, 1\right)$. Since the identity of next period decisive voter's do not change from old to young, the aggregate saving decision rule follows: $S\left(k_{t}, \pi_{t}=\left(\frac{\Psi}{\Psi+1}, 1\right), \tau_{t+1}=\frac{\Psi}{\Psi+1}\right)$.

\subsection{A model without a social security system:}

In order to emphasis the role of the social security system in the model, we next consider a similar model with private saving, but without transfer payments from the young to the old. We will prove that there is an equilibrium that incorporates two strategies depending on the population growth rates. If the immigration quota preferred by the young for its direct effects on wages, is low enough, the young decisive voter will restrict immigration even further, in order to change next period decisive voter from young to old, so that next period old decisive voter will set no restrictions on immigration. This policy is favorable 
because it raises the return on savings of the current young. If the immigration quota preferred by the young, for its direct effect on wages, is high enough, the young decisive voter will not manipulate next period young to old ratio, and set his preferable immigration quota at a level equal to the next period quota set by next period young decisive voter. Note that since there is no social security system, there is no additional equilibrium as in the previous model. This is due to the fact that the "demographic steady" strategy of this equilibrium results from the dependency of the tax rate cum benefit rate on the capital per (native born) worker, which does not exist in the present model.

The absence of social security system simplifies the assumptions of the model, as follows:

The utility of the representative young and old individuals are derived only from their own earned income and saving,

$$
\begin{gathered}
U^{y}\left(w_{t}, \tau_{t}, s_{t}, r_{t+1}\right)=\log \left(w_{t} l_{t}-s_{t}-\frac{l_{t}^{\Psi+1}}{\Psi+1}\right)+\beta \log \left(\left(1+r_{t+1}\right) s_{t}\right) \\
U^{o}\left(s_{t-1}, r_{t},\right)=\left(1+r_{t}\right) s_{t-1}
\end{gathered}
$$

This generates the standard saving-consumption and labor-leisure decisions:

$$
\begin{gathered}
s_{t}=\frac{1}{1+\beta}\left(\beta \frac{\Psi}{\Psi+1} w_{t} l_{t}\right) \\
l_{t}^{\Psi}=w_{t}
\end{gathered}
$$

Factor prices are determined as in the extended model.

The indirect utility of the young and old respectively can be written as follows:

$$
\begin{aligned}
& V^{y}\left(k_{t}, \gamma_{t}, \gamma_{t+1}\right)=A+(1+\beta) \log \left(\left((1-\alpha) k_{t}^{\alpha}\left(1+\gamma_{t}\right)^{-\alpha}\right)^{\frac{1+\Psi}{\Psi+\alpha}}\right) \\
& +\beta \log \left(\alpha\left((1-\alpha)\left(\frac{\beta}{1+\beta} \frac{\Psi}{\Psi+1} \frac{1+\gamma_{t}}{1+n+\gamma_{t}(1+m)}\left((1-\alpha) k_{t}^{\alpha}\left(1+\gamma_{t}\right)^{-\alpha}\right)^{\frac{1+\Psi}{\Psi+\alpha}}\right)^{-\Psi}\left(1+\gamma_{t+1}\right)^{\Psi}\right)^{\frac{1-\alpha}{\Psi+\alpha}}\right) \\
& V^{o}\left(\gamma_{t-1}, k_{t}\right)=\alpha\left((1-\alpha) k_{t}^{-\Psi}\left(1+\gamma_{t}\right)^{\Psi}\right)^{\frac{1-\alpha}{\Psi+\alpha}} k_{t}\left(\frac{1+n+\gamma_{t-1}(1+m)}{\left(1+\gamma_{t-1}\right)}\right)
\end{aligned}
$$

The definition of the Markov sub-game perfect political equilibrium is similar to the previous definition, but has only one policy decision rule, the immigration policy rule, $\gamma_{t}=G\left(\gamma_{t-1}\right)$. 
Proposition 7 The equilibrium can be specified as follows:

$$
G\left(\gamma_{t-1}\right)=\left\{\begin{array}{c}
\gamma_{t}=\operatorname{Min}\left[\gamma^{*},-\frac{n}{m}\right] \quad \begin{array}{c}
\gamma^{*} \leq \bar{\gamma} \\
\gamma_{t}=\gamma^{*}
\end{array} \quad \text { otherwise } \quad \text { if } \quad u_{t}\left(\gamma_{t-1}\right)<1 \\
\gamma_{t}=1 \quad \text { otherwise } \\
S\left(\gamma_{t}, k_{t}\right)=\frac{\beta}{1+\beta} \frac{\Psi}{\Psi+1} \frac{\left(1+\gamma_{t}\right)}{1+n+\gamma_{t}(1+m)} w_{t} l_{t}
\end{array}\right.
$$

where $\gamma^{*}$ is defined as in the proposition II, and $\bar{\gamma}$ is given implicitly by the following equation:

$\left(\frac{1-\frac{n}{m}}{1+\bar{\gamma}}\right)^{-\alpha(1+\beta) \frac{1+\Psi}{\Psi+\alpha}}\left[\left(\frac{2}{1-\bar{\gamma}}\right)^{\Psi}\left(\frac{\frac{1-\frac{n}{m}}{1+n-\frac{n}{m}(1+m)}}{\frac{1+\bar{\gamma}}{1+n+\bar{\gamma}(1+m)}}\left(\frac{1-\frac{n}{m}}{1+\bar{\gamma}}\right)^{-\alpha(1+\beta) \frac{1+\Psi}{\Psi+\alpha}}\right)^{-\Psi}\right]^{\beta \frac{1-\alpha}{\Psi+\alpha}}=1$

The equilibrium paths depends on the population growth rates and on the initial amount of capital per (native-born) worker the economy is endowed with. There are four types of equilibrium paths: 1 . if $n>0$, there are some restrictions on immigration. 2. if $m+n<0$, there are no restrictions on immigration. 3. if $n<0$ and $m+n>0$, there are two possible equilibrium paths: if $\gamma^{*} \leq \bar{\gamma}$, there is a "demographic switching" equilibrium path, where some level of immigration always prevails: in periods where the decisive voter is old, there are no restrictions on immigration; and in periods where the decisive voter is young, there are some restrictions on immigration. Otherwise, the decisive voter is always young, and there are less restrictions on immigration than in the "demographic switching" equilibrium path when the decisive voter is young.

Proof. As in proposition II, we must show that the immigration policy decision rule, $G$, satisfies the equilibrium conditions.

Consider first the case where there is a majority of old in period $t$, i.e. $u_{t} \geq 1$. It is easy to see that the $V^{o}\left(\gamma_{t-1}, k_{t}\right)$ is maximized by setting $\gamma_{t}=1$.

Consider next the case where there is a majority of young in period $t$, i.e. $u_{t}<1$. We will prove that in the case where $m+n>0$ and $n<0$, the indirect utility of the young, $V^{y}\left(\gamma_{t-1}, k_{t}\right)$, is maximized by $\gamma_{t}=\operatorname{Min}\left[\gamma^{*},-\frac{n}{m}\right]$, if $\gamma^{*} \leq \bar{\gamma}$ and by $\gamma_{t}=\gamma^{*}$ otherwise $^{10}$. As was proved in proposition II, the indirect utility of the young subject to constant next period policy variables, is maximized by

\footnotetext{
${ }^{10}$ If the population growth rates are both positive, $m, n>0$, then it is straightforward to see that $V^{y}\left(\gamma_{t-1}, k_{t}\right)$ is maximized by $\gamma_{t}=\gamma^{*}$.
} 
setting: $\gamma_{t}=\gamma^{*}$, where $\gamma^{*} \in[0,1]$. Define $\bar{\gamma}$ to be the immigration quota which satisfies the following property:

$$
V^{y}\left(k_{t}, \gamma_{t}=-\frac{n}{m}, \gamma_{t+1}=1\right)=V^{y}\left(k_{t}, \gamma_{t}=\bar{\gamma}, \gamma_{t+1}=\bar{\gamma}\right)
$$

The indirect utility of the young voter subject to: $\gamma_{t+1}=\Psi\left(\gamma_{t}\right)$, can be written in the following way:

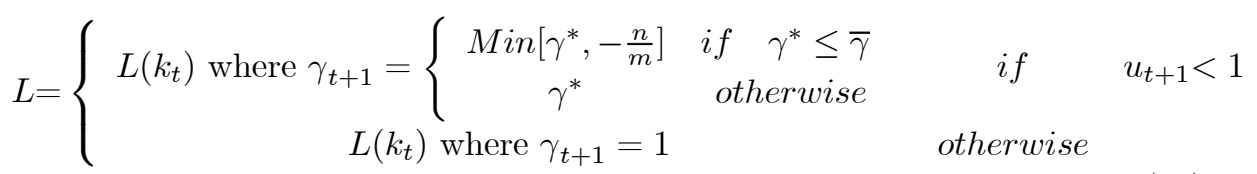

where $L\left(k_{t}\right)$ is defined as follows:

$L\left(k_{t}\right)=\left\{\begin{array}{l}A+(1+\beta) \log \left(\left((1-\alpha) k_{t}^{\alpha}\left(1+\gamma_{t}\right)^{-\alpha}\right)^{\frac{1+\Psi}{\Psi+\alpha}}\right) \\ +\beta \log \left(\alpha\left((1-\alpha)\left(\frac{\beta}{1+\beta} \frac{\Psi}{\Psi+1} \frac{1+\gamma_{t}}{1+n+\gamma_{t}(1+m)}\left((1-\alpha) k_{t}^{\alpha}\left(1+\gamma_{t}\right)^{-\alpha}\right)^{\frac{1+\Psi}{\Psi+\alpha}}\right)^{-\Psi}\left(1+\gamma_{t+1}\right)^{\Psi}\right)^{\frac{1-\alpha}{\Psi+\alpha}}\right)\end{array}\right.$

It is easy to see that if $\gamma^{*} \leq-\frac{n}{m}$, then the young decisive voter will set the current immigration quota to be $\gamma_{t}=\gamma^{*}$. Otherwise $\gamma^{*}>-\frac{n}{m}$. If additionally the optimal immigration quota satisfy the property: $\bar{\gamma}<\gamma^{*}$, we have to prove that the optimal strategy of the young is to set according to: $\gamma_{t}=\gamma^{*}$, which will induce a young decisive voter in the next period voting for the same strategy, meaning:

$$
V^{y}\left(k_{t}, \gamma_{t}=-\frac{n}{m}, \gamma_{t+1}=1\right)<V^{y}\left(k_{t}, \gamma_{t}=\gamma^{*}, \gamma_{t+1}=\gamma^{*}\right)
$$

Using the fact the indirect utility of the young is higher the higher is next period immigration quotas (as it increases the next period interest rate), we derive, from equation (93), the following inequality:

$V^{y}\left(k_{t}, \gamma_{t}=-\frac{n}{m}, \gamma_{t+1}=1\right)=V^{y}\left(k_{t}, \gamma_{t}=\bar{\gamma}, \gamma_{t+1}=\bar{\gamma}\right)<V^{y}\left(k_{t}, \gamma_{t}=\gamma^{*}, \gamma_{t+1}=\gamma^{*}\right)$

Thus, the optimal strategy of the young when $\gamma^{*}>-\frac{n}{m}$ and $\bar{\gamma}<\gamma^{*}$ is to set the immigration quota to be: $\gamma_{t}=\gamma^{*}$. Otherwise, if $\gamma^{*}>-\frac{n}{m}$, but the optimal immigration quota satisfies the property: $\bar{\gamma} \geq \gamma^{*}$, we must prove that the young will set the immigration quota to be: $\gamma_{t}=-\frac{n}{m}$, which will induce an old decisive voter in the next period voting for $\gamma_{t+1}=1$, meaning:

$$
V^{y}\left(k_{t}, \gamma_{t}=-\frac{n}{m}, \gamma_{t+1}=1\right)>V^{y}\left(k_{t}, \gamma_{t}=\gamma^{*}, \gamma_{t+1}=-\frac{n}{m}\right)
$$


which can be rewritten in the following way:

$$
\left(\frac{1-\frac{n}{m}}{1+\gamma^{*}}\right)^{-\alpha(1+\beta) \frac{1+\Psi}{\Psi+\alpha}}\left[\left(\frac{2}{1-\frac{n}{m}}\right)^{\Psi}\left(\frac{\frac{1-\frac{n}{m}}{1+n-\frac{n}{m}(1+m)}}{\frac{1+\gamma^{*}}{1+n+\gamma^{*}(1+m)}}\left(\frac{1-\frac{n}{m}}{1+\gamma^{*}}\right)^{-\alpha(1+\beta) \frac{1+\Psi}{\Psi+\alpha}}\right)^{-\Psi}\right]^{\beta \frac{1-\alpha}{\Psi+\alpha}}>1
$$

Since $\gamma^{*} \leq 1$, it is enough to prove that:

$$
\left(\frac{1-\frac{n}{m}}{1+\gamma^{*}}\right)^{-\alpha(1+\beta) \frac{1+\Psi}{\Psi+\alpha}}\left[\left(\frac{1+\gamma^{*}}{1-\frac{n}{m}}\right)^{\Psi}\left(\frac{\frac{1-\frac{n}{m}}{1+n-\frac{n}{m}(1+m)}}{\frac{1+\gamma^{*}}{1+n+\gamma^{*}(1+m)}}\left(\frac{1-\frac{n}{m}}{1+\gamma^{*}}\right)^{-\alpha(1+\beta) \frac{1+\Psi}{\Psi+\alpha}}\right)^{-\Psi}\right]^{\beta \frac{1-\alpha}{\Psi+\alpha}}>1
$$

Denote by $k(y)$ the following function:

$k(y)=\left(\frac{1}{1+y}\right)^{-\alpha(1+\beta) \frac{1+\Psi}{\Psi+\alpha}}\left[(1+y)^{\Psi}\left(\frac{1}{\frac{1+y}{1+n+y(1+m)}}\left(\frac{1}{1+y}\right)^{-\alpha(1+\beta) \frac{1+\Psi}{\Psi+\alpha}}\right)^{-\Psi}\right]^{\beta \frac{1-\alpha}{\Psi+\alpha}}$

Since the derivative of $k(y)$ by $y$ is positive for $-\frac{n}{m} \leq y \leq 1$, it means that $k\left(\gamma^{*}\right)>k\left(-\frac{n}{m}\right)$. Thus, the optimal strategy of the young in that case is to set the immigration quota to be $\gamma_{t}=-\frac{n}{m}$, which completes the proof.

\section{References}

[1] Becker, G.S., Mulligan, C., 2003. Deadweight costs and the size of government. The Journal of Law and Economics 46, 293-340.

[2] Benhabib, J., 1996. On the political economy of immigration. European Economic Review 40, 1737-43

[3] Bergstrom, T.C., Hartman, J.L., 2005. Sustainabillity of pay-as-you-go social security, Cesifo Working Paper No.1378.

[4] Bohn, Henning, , 2005. Will Social Security and Medicare Remain Viable as the U.S. Population is

[5] Aging? An Update, in: Robin Brooks and Assaf Razin (eds.), The Politics and Finance of

[6] Social Security Reform, Cambridge University Press, 44-72

[7] Boldrin, M., Rustichini, A., 2000. Political equilibria with social security. Review of Economic Dynamics 3, 41-78. 
[8] Borjas, G.J., 1999. Heaven's door: immigration policy and the american economy. Princeton University Press, Princeton, N.J.

[9] Breyer, F., Craig, B., 1997. Voting on social security: evidence from OECD countries. European Journal of Political Economy 13, 705-724.

[10] Cooley, T.F., Soares, J., 1999. A positive theory of social security based on reputation. Journal of Political Economy 107, 135- 160.

[11] Dolmas, J., Huffman G.W., 2004. On the political economy of immigration and income redistribution. International Economic Review 45, 1129-1168.

[12] Feldstein M.S., 2006. The effects of the ageing european population on economic growth and budgets: implications for immigration and other policies. NBER working paper \#12736, Cambridge, Mass.

[13] Forni, L,. 2005, Social security as Markov equilibrium in OLG models. Review of Economic Dynamics 8, 178-194.

[14] Galasso, V., Profeta, P., 2002. The political economy of social security: a survey. European Journal of Political Economy 18, 1- 29.

[15] Hansson, I., Stuart, C., 1989. Social security as trade among living generations. American Economic Review 79, 549-559.

[16] Hassler, J., Rodriguez Mora, J. V., Storesletten, K., Zilliboti, F., 2003. The survival of the welfare state, American Economic Review 93,. 87-112, 2003.

[17] Krusell, P., Rios-Rull, J.V., 1996. Vested interests in a positive theory of stagnation and growth. Review of Economic Studies 63, 301-29.

[18] Lee, R., Miller, T.,2000. Immigration, social security, and broader fiscal impacts. The American Economic Review 90, 350-354.

[19] Mulligan, C.B., Sala-i-Martin, X., 1999. Gerontocracy, retirement and social security. NBER working paper \#7117, Cambridge, Mass.

[20] Ortega, F., 2005. Immigration quotas and skill upgrading. Journal of Public Economics 89, 1841-1863.

[21] Razin, A., Sadka, E., 2000. Unskilled migration: a burden or a boon for the welfare state. Scandinavian Journal of Economics 102, 463-479.

[22] Razin, A., Sadka, E., Swagel, P., 2002a. The aging population and the size of the welfare state. Journal of Political Economy 110, 900-918. 
[23] Razin, A., Sadka, E., Swagel, P., 2002b. Tax burden and migration: a political economy theory and evidence, Journal of Public Economics 85,167-190.

[24] Razin, A., Sadka, E., 2004.Welfare migration: is the net fiscal burden a good measure of its economic impact on the welfare of the native-born population? CESifo Economic Studies 50, 709-714.

[25] Tabellini, G., 2000. A positive theory of social security. Scandinavian Journal of Economics 102, 523- 545 .

[26] Storesletten, K., 2000. Sustaining fiscal policy through immigration. The Journal of Political Economy 108, 300-24.

[27] Verbon, H.A.A., Verhoeven, M.J.M., 1992. Decision making on pension schemes under rational expectations. Journal of Economics 56, 71- 97. 


\section{CESifo Working Paper Series}

(for full list see www.cesifo-group.de)

1916 Ian Babetskii, Aggregate Wage Flexibility in Selected New EU Member States, February 2007

1917 Burkhard Heer, Alfred Maussner and Paul D. McNelis, The Money-Age Distribution: Empirical Facts and Limited Monetary Models, February 2007

1918 Yin-Wong Cheung, Menzie D. Chinn and Eijii Fujii, The Overvaluation of Renminbi Undervaluation, February 2007

1919 Jim Malley, Apostolis Philippopoulos and Ulrich Woitek, To React or Not? Fiscal Policy, Volatility and Welfare in the EU-3, February 2007

1920 Mattias Polborn, Competing for Recognition through Public Good Provision, February 2007

1921 Lars P. Feld and Benno Torgler, Tax Morale after the Reunification of Germany: Results from a Quasi-Natural Experiment, February 2007

1922 Robert S. Chirinko and Huntley Schaller, Fundamentals, Misvaluation, and Investment: The Real Story, February 2007

1923 Benno Torgler and Friedrich Schneider, Shadow Economy, Tax Morale, Governance and Institutional Quality: A Panel Analysis, February 2007

1924 Adrian Pagan and M. Hashem Pesaran, On Econometric Analysis of Structural Systems with Permanent and Transitory Shocks and Exogenous Variables, February 2007

1925 Hans-Werner Sinn, The Welfare State and the Forces of Globalization, February 2007

1926 Michael Smart, Raising Taxes through Equalization, February 2007

1927 Øystein Foros, Kåre P. Hagen and Hans Jarle Kind, Price-Dependent Profit Sharing as an Escape from the Bertrand Paradox, February 2007

1928 Balázs Égert, Kirsten Lommatzsch and Amina Lahrèche-Révil, Real Exchange Rates in Small Open OECD and Transition Economies: Comparing Apples with Oranges?, February 2007

1929 Aleksander Berentsen and Cyril Monnet, Monetary Policy in a Channel System, February 2007

1930 Wolfgang Ochel, The Free Movement of Inactive Citizens in the EU - A Challenge for the European Welfare State?, February 2007 
1931 James K. Hammitt and Nicolas Treich, Statistical vs. Identified Lives in Benefit-Cost Analysis, February 2007

1932 Wilhelm Kohler, The Bazaar Effect, Unbundling of Comparative Advantage, and Migration, February 2007

1933 Karsten Staehr, Fiscal Policies and Business Cycles in an Enlarged Euro Area, February 2007

1934 Michele Bernasconi and Paola Profeta, Redistribution or Education? The Political Economy of the Social Race, March 2007

1935 Axel Dreher, Martin Gassebner and Lars-H. R. Siemers, Does Terror Threaten Human Rights? Evidence from Panel Data, March 2007

1936 Naércio Aquino Menezes Filho and Marc-Andreas Muendler, Labor Reallocation in Response to Trade Reform, March 2007

1937 Gebhard Flaig and Timo Wollmershaeuser, Does the Euro-zone Diverge? A Stress Indicator for Analyzing Trends and Cycles in Real GDP and Inflation, March 2007

1938 Michael Funke and Michael Paetz, Environmental Policy Under Model Uncertainty: A Robust Optimal Control Approach, March 2007

1939 Byeongchan Seong, Sung K. Ahn and Peter A. Zadrozny, Cointegration Analysis with Mixed-Frequency Data, March 2007

1940 Monika Bütler and Michel André Maréchal, Framing Effects in Political Decision Making: Evidence from a Natural Voting Experiment, March 2007

1941 Giacomo Corneo and Olivier Jeanne, A Theory of Tolerance, March 2007

1942 Qing Hong and Michael Smart, In Praise of Tax Havens: International Tax Planning and Foreign Direct Investment, March 2007

1943 Yin-Wong Cheung, Dickson Tam and Matthew S. Yiu, Does the Chinese Interest Rate Follow the US Interest Rate?, March 2007

1944 Panu Poutvaara and Mikael Priks, Unemployment and Gang Crime: Could Prosperity Backfire?, March 2007

1945 Burkhard Heer, On the Modeling of the Income Distribution Business Cycle Dynamics, March 2007

1946 Christoph A. Schaltegger and Lars P. Feld, Are Fiscal Adjustments less Successful in Decentralized Governments?, March 2007

1947 Giovanni Facchini, Marcelo Olarreaga, Peri Silva and Gerald Willmann, Substitutability and Protectionism: Latin America's Trade Policy and Imports from China and India, March 2007 
1948 C. Mirjam van Praag and Bernard M. S. van Praag, The Benefits of Being Economics Professor A (and not Z), March 2007

1949 Astrid Hopfensitz and Frans van Winden, Dynamic Choice, Independence and Emotions, March 2007

1950 Guglielmo Maria Caporale and Luis A. Gil-Alana, A Multivariate Long-Memory Model with Structural Breaks, March 2007

1951 Mattias Ganslandt and Keith E. Maskus, Wholesale Price Discrimination and Parallel Imports, March 2007

1952 Michela Redoano, Fiscal Interactions Among European Countries. Does the EU Matter?, March 2007

1953 Stefan C. Wolter, Rémy Hübschi and Matthias Müller, Push or Pull? An Empirical Analysis of the Demand for Individual Project Grants from the Swiss National Science Foundation, March 2007

1954 Scott Alan Carson, African-American and White Inequality in the American South: Evidence from the $19^{\text {th }}$ Century Missouri State Prison, March 2007

1955 Peter Egger, Marko Koethenbuerger and Michael Smart, Do Fiscal Transfers Alleviate Business Tax Competition? Evidence from Germany, March 2007

1956 Panu Poutvaara and Lars-H. R. Siemers, Smoking and Social Interaction, March 2007

1957 Stephan Danninger and Fred Joutz, What Explains Germany’s Rebounding Export Market Share?, March 2007

1958 Stefan Krasa and Mattias Polborn, Majority-efficiency and Competition-efficiency in a Binary Policy Model, March 2007

1959 Thiess Buettner and Georg Wamser, Intercompany Loans and Profit Shifting Evidence from Company-Level Data, March 2007

1960 Per Pettersson-Lidbom and Mikael Priks, Behavior under Social Pressure: Empty Italian Stadiums and Referee Bias, April 2007

1961 Balázs Égert and Carol S. Leonard, Dutch Disease Scare in Kazakhstan: Is it real?, April 2007

1962 Paul De Grauwe and Pablo Rovira Kaltwasser, Modeling Optimism and Pessimism in the Foreign Exchange Market, April 2007

1963 Volker Grossmann and Thomas M. Steger, Anti-Competitive Conduct, In-House R\&D, and Growth, April 2007

1964 Steven Brakman and Charles van Marrewijk, It’s a Big World After All, April 2007 
1965 Mauro Ghinamo, Paolo M. Panteghini and Federico Revelli, FDI Determination and Corporate Tax Competition in a Volatile World, April 2007

1966 Inés Macho-Stadler and David Pérez-Castrillo, Optimal Monitoring to Implement Clean Technologies when Pollution is Random, April 2007

1967 Thomas Eichner and Ruediger Pethig, Efficient $\mathrm{CO}_{2}$ Emissions Control with National Emissions Taxes and International Emissions Trading, April 2007

1968 Michela Redoano, Does Centralization Affect the Number and Size of Lobbies?, April 2007

1969 Christian Gollier, Intergenerational Risk-Sharing and Risk-Taking of a Pension Fund, April 2007

1970 Swapan K. Bhattacharya and Biswa N. Bhattacharyay, Gains and Losses of India-China Trade Cooperation - a Gravity Model Impact Analysis, April 2007

1971 Gerhard Illing, Financial Stability and Monetary Policy - A Framework, April 2007

1972 Rainald Borck and Matthias Wrede, Commuting Subsidies with two Transport Modes, April 2007

1973 Frederick van der Ploeg, Prudent Budgetary Policy: Political Economy of Precautionary Taxation, April 2007

1974 Ben J. Heijdra and Ward E. Romp, Retirement, Pensions, and Ageing, April 2007

1975 Scott Alan Carson, Health during Industrialization: Evidence from the $19^{\text {th }}$ Century Pennsylvania State Prison System, April 2007

1976 Andreas Haufler and Ian Wooton, Competition for Firms in an Oligopolistic Industry: Do Firms or Countries Have to Pay?, April 2007

1977 Eckhard Janeba, Exports, Unemployment and the Welfare State, April 2007

1978 Gernot Doppelhofer and Melvyn Weeks, Jointness of Growth Determinants, April 2007

1979 Edith Sand and Assaf Razin, The Role of Immigration in Sustaining the Social Security System: A Political Economy Approach, April 2007 